\title{
THE NEW WILD WEST: MEASURING AND PROVING FAME AND DILUTION UNDER THE FEDERAL TRADEMARK DILUTION ACT
}

\author{
Xuan-Thao N. Nguyen*
}

\section{INTRODUCTION}

The passage of the Federal Trademark Dilution Act of 1995 (the Dilution Act or Act) has been widely celebrated, as evidenced by the number of related articles, speeches and symposia. ${ }^{1}$ Commentators who applauded the adoption of the Dilution Act believed that a dilution claim would now be easier to prove by trademark owners against diluters because trademark owners would not have to establish the troublesome factual issue of consumer confusion. ${ }^{2}$ The courts have embraced the Act, and it has already proven to be an effective weapon for trademark owners. ${ }^{3}$ One court has even suggested trademark owners asserting claims of dilution bear a lighter

* B.A., Oberlin College, 1990; J.D., Northeastern University School of Law, 1995. Former Associate, Fried, Frank, Harris, Shriver \& Jacobson, 1995-1999. Ms. Nguyen is currently an Associate at Pryor, Cashman, Sherman \& Flynn. The author sincerely thanks Karen Bravo of Hale \& Dorr and Elena Adolphus of Fried, Frank, Harris, Shriver \& Jacobson for their valuable comments. Many thanks to Michael West and members of Albany Law Review for their diligence. Special thanks to Erik Darwin Hille and Khai-Leif Nguyen-Hille for their generous love and support during the writing of this article.

1 See, e.g., Dilution AND Famous Marks For ADVANCEd TRADEMaRK PRACTITIONERS (International Trademark Association ed., 1998) (course materials, on file with Albany Law Review); see also Pub. L. No. 104-98, 109 Stat. 985 (1996) (illustrating the applicable statute).

2 See Paul Heald, Sunbeam Products, Inc. v. The West Bend Co.: Exposing the Malign Application of the Federal Dilution Statute to Product Configurations, 5 J. INTELL. ProP. L. $415,416-17$ (1998) ("[A] suit for dilution is easier to prove than infringement because the troublesome factual question of consumer confusion is not relevant.").

3 See Stephen F. Mohr, The New Federal Trademark Dilution Act: Expanding the Rights of Trademark Owners, in Annual Advanced Seminar on Trademark Law 1997, 9, 9 (PLI Pat., Copyrights, Trademarks \& Literary Prop. Course Handbook series No. G-476, 1997) ("The Dilution Act has already proven to be an effective weapon for owners of arguably wellknown or 'famous' trademarks to prevent a wide range of third party uses of marks similar or identical to such marks."); see also Melanie M. Routh, Note, Trademark Dilution and the Effect of the Federal Trademark Dilution Act, 50 RUTGERS L. REV. 253, 255 (1997) (reviewing seventeen cases that have applied the Act and concluding that courts have given the dilution theory a newfound respect and are more willing to recognize dilution as an individual cause of action). 
burden than that required under section 43(a) of the Lanham Act because they do not have to demonstrate competition between the owners and the diluters or a likelihood of confusion as to the source of the products or services. ${ }^{4}$

As three years have gone by since the Act first went into effect, it has become clear that proving dilution under the Act is not as easy as many had previously thought. Indeed, the Fourth Circuit, in Ringling Bros.-Barnum \& Bailey Combined Shows, Inc. v. Utah Division of Travel Development,${ }^{5}$ has recently begun an open season in the Wild West of dilution land by requiring proof of actual economic harm to the famous mark's selling power. ${ }^{6}$

The problems encountered by trademark owners attempting to pursue a dilution claim are inherent in the Act itself. The Act provides no concrete guidance on how fame and dilution should be measured or proven. ${ }^{7}$ This limitation has led judicial interpretation of the Act to a new Wild West where courts confront the task of measuring fame and dilution without the benefit of any criteria for making such measurements. ${ }^{8}$ In analyzing the Act, no court has provided a cut-off percentage for finding fame and/or dilution under either the likelihood of dilution or actual dilution standard. As a result, a wasteland of case law has developed with cases that either superficially ${ }^{9}$ or erroneously ${ }^{10}$ analyze dilution claims or avoid the dilution issue altogether by finding trademark infringement under the traditional theory of likelihood of confusion. ${ }^{11}$ Consequently,

4 See Clinique Labs., Inc. v. Dep Corp., 945 F. Supp. 547, 561 (S.D.N.Y. 1996) (discussing the standards for analyzing dilution claims).

5955 F. Supp. 605 (E.D. Va. 1997), aff'd, 170 F.3d 449 (4th Cir. 1999).

6 See id. at 453 (maintaining that actual harm to a senior mark's economic value as a product-identifying and advertising agent must be proven). The Second Circuit recently entered the Wild West of dilution land by endorsing the likelihood of dilution standard. See Nabisco, Inc. v. PF Brands, Inc., No. 99-7149(L), 1999 WL 672575, at *18 (2d Cir. Aug. 31, 1999), affg, 50 F. Supp.2d 188, 201 (S.D.N.Y. 1999). However, that court provided no guidance on fame and dilution measurement. See id. at ${ }^{*} 12-18$.

7 See generally J. THOMAS MCCARTHY, 3 MCCARTHY ON TRADEMARKS AND UNFAIR COMPETITION, $\S 24: 89-90$, at 24-138 to -141 (4th ed. 1997) (discussing significant points of the. Federal Trademark Dilution Act and the factors to determine which marks are famous).

8 See infra notes 62-69 and accompanying text (discussing lack of guidance in measuring fame and dilution).

9 See infra note 77 and accompanying text (discussing America Online v. LCGM, Inc., 46 F. Supp.2d 444 (E.D. Va. 1998)).

10 See infra note 79 and accompanying text (analyzing Acxiom Corp. v. Axiom, Inc. 27 F. Supp.2d 478 (D. Del. 1998)).

11 See infra notes 81-84 and accompanying text (demonstrating the analysis of dilution claims as add-ons to trademark infringement actions and discussing how courts have ignored dilution claims upon finding a likelihood of confusion). 
trademark owners who wish to assert dilution claims are faced with the harsh reality that, despite all the fanfare about the passage of the Act, getting protection under the Act is difficult, given the current inconsistent and incoherent jurisprudence addressing the measurement and proof of fame and dilution. ${ }^{12}$

This Article will attempt to conquer that new Wild West. Section I provides an overview of the Act, explains two traditional theories of dilution-tarnishment and blurring-and discusses the new diminishment theory of dilution recognized by courts in cases involving domain names on the Internet. ${ }^{13}$ Section II explores the limitations of the Act. ${ }^{14}$ Section III examines four authoritative cases that have addressed quantitative measurements of fame and/or dilution, and discusses the shortcomings in each case with regard to quantitative measurements. ${ }^{15}$ Section IV suggests a new approach to measuring and proving fame and dilution. ${ }^{16}$ This Article concludes with the assertion that this proposed approach would arm trademark owners with certainty in navigating the new Wild West of dilution claims analysis under the Dilution Act. ${ }^{17}$

\section{OVERVIEW OF THE FEDERAL DILUTION ACT OF 1995}

Fifty years after the enactment of the first state anti-dilution statute, the 1996 Federal Trademark Dilution Act went into effect. ${ }^{18}$ The Act amended the existing federal Trademark Act of 1946, commonly known as the Lanham Act. ${ }^{19}$ The new Act provided the owner of a famous trademark injunctive relief against unauthorized use of a mark that dilutes the distinctive quality of the famous mark. ${ }^{20}$ The Act, signed into law by President Clinton on January

12 See infra notes $62-84$ and accompanying text (discussing the "wasteland of case law" that has resulted from the wrong interpretation of the Dilution Act).

13 See infra notes 18.51 and accompanying text.

14 See infra notes 52.84 and accompanying text.

15 See infra notes 85-208 and accompanying text.

16 See infra notes $209-75$ and accompanying text.

17 See infra note 276 and accompanying text.

18 See Pub. L. No. 104-98, 109 Stat. 985 (1996); see also Lynda J. Oswald, "Tarnishment" and "Blurring" Under the Federal Trademark Dilution Act of 1996, 36 AM. Bus. L.J. 255, 264 (1999) (analyzing the development of dilution law); Routh, supra note 3, at 257 (discussing the origins of trademark dilution and its history in the United States).

19 See 15 U.S.C. $\$ 1125$ (1994).

20 See id. $\$ 1125(a)(1)$ (discussing what a party must do in order to be held liable for dilution). Other provisions of section $\mathbf{4 3}$ of the Lanham Act provide a cause of action for owners of marks, regardless of whether the marks are registered against unauthorized use that causes false representation, association, sponsorship, advertisement and unfair competition. See id. (providing for civil action remedies); see also Joseph P. Bauer, A Federal Law of Un- 
16, 1996, specifically amended section 43 of the Lanham Act, by adding the following subsection:

The owner of a famous mark shall be entitled, subject to the principles of equity and upon such terms as the court deems reasonable, to an injunction against another person's commercial use in commerce of a mark or trade name, if such use begins after the mark has become famous and causes dilution of the distinctive quality of the [famous] mark ....21

Not all marks should be entitled to anti-dilution protection. As a threshold matter, the Dilution Act requires the mark to be "famous."22 The Act provides eight non-exclusive factors for courts to consider in determining whether a mark is distinctive and famous:

(A) the degree of inherent or acquired distinctiveness of the mark;

(B) the duration and extent of use of the mark in connection with the goods or services with which the mark is used;

(C) the duration and extent of advertising and publicity of the mark;

(D) the geographical extent of the trading area in which the mark is used;

(E) the channels of trade for the goods or services with which the mark is used;

(F) the degree of recognition of the mark in the trading areas and channels of trade used by the marks' owner and the person against whom the injunction is sought;

(G) the nature and extent of use of the same or similar marks by third parties; and

(H) whether the mark was registered under the Act of March 3, 1881, or the Act of February 20, 1905, or on the principal register. ${ }^{23}$

fair Competition: What Should Be the Reach of Section 43(a) of the Lanham Act, 31 UCLA L. REV. 671, 704 (1984) (stating a cause of action exists for the owner of a federally registered trademark when "the unauthorized use of marks or symbols which become associated with a producer's goods ... is likely to confuse customers"). The statute also provides that other remedies, including damages and attorneys' fees, can be awarded if it is shown that the defendant "willfully intended to trade on the owner's reputation or to cause dilution of the famous mark." 15 U.S.C. $§ 1125$ (c)(2) (1994).

2115 U.S.C. $\S 1125$ (c) (1994); see also Pub. L. No. 104-98, 109 Stat. 985 (1996).

22 See id. $\S 1125(\mathrm{c})(1)$.

23 Id. 
A famous mark, however, is not protected under the Dilution Act if it has not been diluted. Pursuant to the Act, dilution is defined as "the lessening of the capacity of a famous mark to identify and distinguish goods or services, regardless of the presence or absence of (1) competition between the owner of the famous mark and other parties, or (2) likelihood of confusion, mistake or deception."24 This definition was formulated recognizing that famous trademarks deserve national protection from "subsequent uses that blur the distinctiveness of the mark or tarnish or disparage it, even in the absence of a likelihood of confusion," and that the then existing protection was "a patch-quilt system of protection, in that only approximately twenty-five states have laws that prohibit trademark dilution." 25 Moreover, the prior enactment of section 43 of the Lanham Act was thought inadequate to protect an owner of a famous trademark against unauthorized diluting use. ${ }^{26}$

Under the Lanham Act's previous enactment, the owner of a famous trademark was required to establish a likelihood of confusion between the famous trademark and the diluter's mark, otherwise known as a junior mark. ${ }^{27}$ The likelihood of confusion was an unnecessary required element of proof of dilution since dilution occurs when consumers who come into contact with the junior mark are not confused as to the source of the product or service denoted by that mark. ${ }^{28}$ For example, consumers who see BUICK shoes will not think that the shoes come from the same source as BUICK cars. Although the consumers are not confused as to the source of the

24 See id. $\S 1127$.

25 H.R. REP. No. 104-374, at 2-3 (1995).

26 See id. at 4 (discussing the reluctance of other nations "to change their laws to protect famous U.S. marks if the U.S. itself does not afford special protection for such marks").

27 See 15 U.S.C. $\$ 1125$ (a), (b) (1994) (setting forth the elements necessary for establishing a civil cause of action against a party using a false designation of origin or description). There is a significant difference between dilution and likelihood of confusion. That difference was recently illustrated in a clarifying footnote contained in an opinion rendered by the Eighth Circuit:

[T] a parent says to the kids, "Let's go pick something out at Blockbuster tonight," and the youngest child assumes they will be buying fireworks made by Viacom, that is evidence of the confusion that is essential to a claim of trademark infringement. But if the oldest child answers, "Which Blockbuster," that evidences dilution by blurring.

Viacom, Inc. v. Ingram Enters., Inc., 141 F.3d 886, 891 n.9 (8th Cir. 1998). See Routh, supra note 3 , at 254 (discussing the difference between dilution and infringement). But see Terry R. Bowen, The Federal Trademark Dilution Act of 1995-Does It Address the Dilution Doctrine's Most Serious Problems? 7 DEPAUL-LCA J. ART \& ENT. L. 75, 92 (1996) (assessing the redundancy between dilution and infringement).

28 See MCCARTHY, supra note 7, § 24:70, at 24-117 (discussing the difference between dilution and the likelihood of confusion). 
products, the use of the BUICK mark on shoes will still weaken the power of the BUICK mark to identify and distinguish its cars. Accordingly, recognizing how dilution of a famous mark occurs, the Dilution Act does not require the owner of a famous mark to establish likelihood of confusion in proving dilution. ${ }^{29}$

Furthermore, the Dilution Act is intended to encompass "all forms of dilution recognized by the courts, including dilution by blurring, by tarnishment and disparagement, and by diminishment." ${ }^{0}$ Nevertheless, the Dilution Act is often seen as being primarily rooted in two traditional theories of dilution: tarnishment and blurring. ${ }^{31}$

\section{A. Tarnishment}

Dilution through tarnishment occurs when a famous mark is improperly associated with an inferior, unwholesome or offensive product or service. ${ }^{32}$ Tarnishment diminishes the goodwill and reputation of the famous mark, particularly when the unauthorized use of the mark involves illegal drugs, pornography or sexual crudity. ${ }^{33}$

29 See id. $\S 24: 90$, at 24-138 ("A Famous Mark Can be Diluted Without Any Likelihood of Confusion.").

30 H.R. REP. NO. 104-374, at 8 (1995).

31 See MCCARTHY, supra note 7, § 24:68-69, at 24-115 to -116 (discussing the types of dilution accepted by the courts and the Restatement); see also Nabisco, Inc. v. PF Brands, Inc., 50 F. Supp.2d 188, 201 (S.D.N.Y. 1999), affd, No. 99-7149L, 1999 WL 672575, at *18 (2d Cir. Aug. 31, 1999) (maintaining a likelihood of dilution can be established by a showing of either tarnishment or blurring); Viacom Inc., 141 F.3d at 888 (noting the Dilution Act protects famous trademarks "from subsequent uses that tarnish or disparage or blur the distinctiveness of the mark, regardless of the likelihood of customer confusion"); Ringling Bros.-Barnum \& Bailey Combined Shows, Inc. v. Utah Div. of Travel Dev., 955 F. Supp 605, 614 (E.D. Va. 1997) ("Although the Act does not specifically mention either [blurring or tarnishment], both are appropriate elucidations of the dilution concept given that both were contemplated by the Act's drafters and are consistent with the Act's purpose."), aff'd, 170 F.3d 449 (4th Cir. 1999); Star Markets, Ltd. v. Texaco, Inc., 950 F. Supp. 1030, 1033 (D. Haw. 1996) ("Dilution may be established by showing tarnishment or blurring.").

32 See Ringling Bros., 955 F. Supp. at 614 ("Dilution through tarnishing can occur where an accused, junior mark is used on unwholesome or inferior goods or services that may create a negative association with the goods or services covered by the famous mark.").

33 See Edgar Rice Burroughs, Inc. v. Manns Theatres, 195 U.S.P.Q. (BNA) 159, 161 (C.D. Cal. 1976) (illustrating the use of the fictitious character TARZAN in X-rated film would di. lute the value of its famous mark); Coca-Cola Co. v. Gemini Rising, Inc., 346 F. Supp. 1183, 1190-91 (E.D.N.Y. 1972) (discussing how the use of ENJOY COCAINE in a script and color identical to the COCA-COLA trade dress would likely be injurious to the reputation of COCA-COLA). 
A claim of dilution through tarnishment, however, has a limited scope. Tarnishment may not cover a defendant's unauthorized use of a mark for products or services that do not involve "obscenity or sexual or illegal activity." 34 One court has held an unauthorized use of a mark for cheap imitation of the trademark owner's products does not amount to tarnishment of the mark because such use is not unwholesome and the trademark owner will not suffer negative association through defendant's use of the mark for cheap imitation products. ${ }^{35}$

\section{B. Blurring}

Blurring occurs when "[c]ustomers or prospective customers ... see the plaintiff's mark used by other persons to identify different sources on a plethora of different goods and services." 36 As a result, the power of the mark to identify and distinguish one source may be weakened. ${ }^{37}$ In other words, blurring occurs when consumers incorrectly associate the famous mark with the junior mark. ${ }^{38}$ This association or confusion is not 'source confusion' as in a trademark infringement action, where consumers seeing the junior mark believe that the goods or services bearing that mark come from, or are in some way associated with, the owner of the senior mark. ${ }^{39}$ In the blurring context, consumers who come in contact with the junior mark make a mental association between the famous mark and the junior mark. ${ }^{40}$ Though the consumers intuitively know that there is no affiliation between the owners of the famous mark and the junior mark, they nevertheless now associate the famous mark with a

34 Clinique Labs., Inc. v. Dep Corp., 945 F. Supp. 547, 562 (S.D.N.Y. 1996).

35 See id. (suggesting famous trademarks cannot succeed on a claim of dilution by tarnishment because famous trademarks will not suffer negative associations from cheap imitations).

36 MCCARTHY, supra note 7, § 24:94, at 24-160.1.

37 See id. ("The unique and distinctive significance of the mark ... may be diluted ....").

38 At least one court has rejected various definitions of blurring "as the use or modification of a famous mark 'to identify the defendant's goods and services,' as a 'whittling away' of the selling power of the mark, and as a use that causes the famous mark to 'no longer ... call immediately to mind' the plaintiffs goods or services." Ringling Bros.-Barnum \& Bailey Combined Shows, Inc. v. Utah Div. of Travel Dev., 955 F. Supp 605, 614 (E.D. Va. 1997) (footnotes omitted), aff'd, 170 F.3d 449 (4th Cir. 1999). Such definitions are not helpful, the court observed, because they beg the question "of what uses of a mark blur or whittle away a famous mark and how this effect can be detected or measured... [and does nothing] more than repeat the words of the Act defining dilution as the lessening of a famous mark's ability to identify goods or services." Id.

39 See id. at 615 ("Source confusion' is irrelevant to the dilution inquiry.").

40 See id. ("Blurring results from an incorrect association ... in consumer's minds."). 
new and different source because of the context in which the junior mark is used. ${ }^{41}$ Thus, the capacity of the famous mark to be a strong identifier of goods or services is weakened. ${ }^{42}$ Over time, blurring will cause the senior mark to lose its ability to serve as a source identifier of the plaintiff s products or services. ${ }^{43}$ Examples of blurring are MIKIMOTO microwave ovens, BMW computers, DUPONT cookies, BUICK telephones and KODAK chairs. ${ }^{44}$

Dilution through blurring, as described above, has been criticized by the Fourth Circuit in its recent determination in Ringling Bros. when the court held that the Dilution Act requires more than consumers' incorrect mental association between the famous mark and the junior mark. ${ }^{45}$ Dilution through blurring, according to the Fourth Circuit, occurs when use of the junior mark has caused actual economic harm to the famous mark's selling power. ${ }^{46}$ The Fourth Circuit is the only court to have interpreted dilution through such stringent blurring.

Although blurring and tarnishment are the traditional and frequently applied theories of dilution, interstate commerce via the Internet has created new varieties of trademark diminishment that do not fall within the boundaries of blurring or tarnishment.

\section{Other Diminishment}

The Dilution Act, as noted above, provides protection for famous marks beyond the two traditional theories of tarnishment and blurring. ${ }^{47}$ Some courts have applied the Act to cases involving domain

41 See generally MCCARTHY, supra note 7, $\$ 24: 68$, at 24-118 (affirming that while the public will discern separate sources, the senior mark will nevertheless lose some uniqueness).

42 See id. (noting "the ability of the senior user's mark to serve as a urique identifier of the plaintiffs goods or services is weakened because the relevant public now also associates that designation with a new and different source").

43 See id. at 24-116 (confirming while the distinguishing significance of a mark will be weakened, there will be no confusion over source or affiliation).

44 See Viacom, Inc. v. Ingram Enters., Inc., 141 F.3d 886, 888 (8th Cir. 1998) (noting the Dilution Act was created to protect trademark owners of non-competing uses such as DUPONT shoes, BUICK aspirin, and KODAK pianos); see also Mohr, supra note 3, at 11 (illustrating examples of blurring considered by Congress while enacting pending legislation).

45 See Ringling Bros., 170 F.3d at 458 (stating "the end harm at which [the Dilution Act] is aimed is a mark's selling power").

46 See id. at 463 ("If you seek to rely for proof of dilution only upon evidence of the mental impressions evoked in consumers upon viewing the marks, then those impressions must go beyond mere recognition of a visual similarity of the two marks . ...").

47 See supra note 23 and accompanying text (enumerating an eight factor analysis for courts to employ when examining dilution claims). 
names on the internet, where the defendant's actions involved neither tarnishment nor blurring. ${ }^{48}$ In these cases, defendants used domain names that are similar to plaintiffs' known marks/domain names. ${ }^{49}$ The defendants, however, provided products or services different from those of the plaintiffs. ${ }^{50}$ The courts held that dilution occurs because prospective users of plaintiffs' services who mistakenly access defendants' web site may fail to continue to search for plaintiffs' own home page due to frustration over having to wade through hundreds of web sites or the belief that plaintiffs' home page does not exist. ${ }^{51}$

At first glance, the Act is a significant development in trademark law. However, by its terms the Act has limitations that unquestionably are causing inconsistent judicial interpretations and imposing difficulties for trademark owners in proving dilution. The next section will explore those limitations.

\section{THE LIMITATIONS OF THE ACT}

\section{A. The Ambiguity Problem with Fame}

The Dilution Act unfortunately provides no instructions for resolving its ambiguous language. The Act mandates that for a mark to enjoy protection it must be "famous," but does not define the

\footnotetext{
48 See, e.g., Panavision Int'l., L.P. v. Toeppen, 141 F.3d 1316, 1326 (9th Cir. 1998) (stating a court need not rely only on blurring or tarnishment to find dilution); TeleTech Customer Care Management, Inc. v. Tele-Tech Co., Inc., 977 F. Supp. 1407, 1413 (C.D. Cal. 1997) (holding the plaintiff was entitled to an injunction under the Lanham Act without a showing that the consumer would be confused by the defendant's use of the plaintiffs mark). But see Jews for Jesus v. Brodsky, 993 F. Supp. 282, 307 (D. N.J. 1998) (maintaining the use by the defendant of the plaintiffs mark to lure consumers to a website where the defendant disparaged the plaintiff amounted to blurring and tarnishment).

49 See Panavision Int'l, 141 F.3d at 1319 (noting the action resulted from the defendant's use of the plaintiffs domain name as its website address); TeleTech Customer Care Management, $977 \mathrm{~F}$. Supp. at 1410 (illustrating how defendant's use of plaintiffs exact domain name minus a hyphen as defendant's website address led to suit).

50 See Panavision Int'l, 141 F.3d at 1319 (illustrating the plaintiff and defendant were neither engaged in the business of manufacturing the same product nor rendering the same services); TeleTech Customer Care Management, 977 F. Supp. at 1409-10 (noting similarities between the business of the plaintiff and that of the defendant ended with similar domain names and website addresses).

51 See Panavision Int'l, 141 F.3d at 1327 (noting dilution occurs when "potential customers of [plaintiff are] discouraged if they cannot find its webpage by typing in 'Panavision.com"'); TeleTech Customer Care Management, 977 F. Supp. at 1410 (finding the use of a search engine can generate as many as 1,000 matches, which is "likely to deter web browsers from searching for Plaintiff's particular website").
} 
term famous. ${ }^{52}$ On one hand, the Act extends protection to famous marks against diluting use of that mark after it has become famous. ${ }^{53}$ On the other hand, the act requires the diluting use to cause "dilution of the distinctive quality of the [famous] mark" and provides eight factors to determine whether the mark is "distinctive and famous." 54 This leads to numerous unanswered questions. Must a mark be both famous and distinctive? Is distinctive a synonym for fame? Should an independent inquiry for distinctiveness be conducted in addition to a fame analysis? What are the factors a mark must possess in order to be distinctive or famous? Can a mark be distinctive and not famous? Is a famous mark automatically a distinctive mark? Is a distinctive mark also a famous mark? Can a famous mark be distinctive? Does distinctive under the Dilution Act have the same meaning as distinctive in the traditional trademark infringement context? Given such ambiguity, it is not a surprise to see that the terms distinctive and famous have been subject to a wide range of interpretations. ${ }^{55}$

52 See 15 U.S.C. $\$ 1125$ (c)(1) (1994). At least one court has attempted to prevent circular reasoning in the application of the enumerated factors to determine whether a mark is distinctive and famous by interpreting the Act to protect "truly famous marks, which are presumed distinctive, but not distinctive marks if they are not also sufficiently famous." Star Markets, Ltd. v. Texaco, Inc., 950 F. Supp. 1030, 1032 (D. Haw. 1996) (footnote omitted); see also Mohr, supra note 3, at 15 (noting the factors of the Dilution Act are similar to those historically addressed by state courts in determining what constitutes sufficient fame). However, some courts confuse fame with distinctiveness. See Elvis Presley Enter., Inc. v. Capece, 950 F. Supp. 783, 797 (S.D. Tex. 1996) (concluding a plaintiff must establish ownership of a distinctive mark to prevail on a dilution claim), rev'd, 141 F.3d 188 (5th Cir. 1998); Clinique Labs., Inc. v. Dep Corp., 945 F. Supp. 547, 561 (S.D.N.Y. 1996) (requiring the plaintiff to demonstrate ownership of a distinctive or famous mark); see also Lori Krafte-Jacobs, Judicial Interpretation of the Federal Trademark Dilution Act of 1995, 66 U. CIN. L. REV. 659, 690 (1998) (affirming that courts often confuse fame with distinctiveness).

53 See 15 U.S.C. $\S 1125$ (c)(1) (1994) (noting the statute becomes applicable only "after the mark has become famous"); see also supra note 23 and accompanying text (setting forth enumerated factors).

5415 U.S.C. $\S 1125(c)(1)$.

55 See, e.g., I.P. Lund Trading ApS v. Kohler Co., 163 F.3d 27, 37 (1st Cir. 1998) ("[N]ational renown is an important factor in determining whether a mark qualifies as famous under the [Dilution Act]. Although the district court found that ... the [mark] is renowned... whether the [mark's] identifying design is sufficiently famous to qualify for the [Act's] protection is far from clear.") (citation omitted) (footnote omitted); Nabisco, Inc. v. PF Brands, Inc., 50 F. Supp. 2d 188, 202 (S.D.N.Y. 1999) (stating distinctiveness as used in the context of dilution "is essentially synonymous for fame"), affd, No. 99-7149(L), 1999 WL 672575 (2d Cir. August 31, 1999) (concluding the Act granted the anti-dilution "privilege only to holders of distinctive marks"); America OnLine, Inc. v. LCGM, Inc., 46 F. Supp. 2d 444, 450 (E.D. Va. 1998) (noting the ownership of a distinctive mark is required for a dilution claim under the Dilution Act); Breuer Elec. Mfg. Co. v. Hoover Co., 48 U.S.P.Q.2d (BNA) 1705, 1718 (N.D. Ill. 1998) ("While these marks are registered and have been used for many years on products sold nationwide, Breuer/Tornado has provided little evidence that these marks 
Moreover, some courts have exhibited sympathy for the "big fish in a small pond" and have erroneously accorded famous status to locally recognized marks. ${ }^{56}$ This problem has also occurred in cases where marks are only recognized within a small niche of an industry. ${ }^{57}$ These cases often involve disputes over domain names on the Internet. ${ }^{58}$ The rapid development of the Internet has become a fertile ground for courts to test the new diminishment theory of dilution.59 It seems, in the Internet cases, that the willingness of the courts to find certain trademarks in small markets to be famous indicates a judicial desire to accommodate the Congressional intent to combat cyber-squatters and curb the use of deceptive domain names. ${ }^{60}$ In the non-Internet area, some courts have found famous marks that have gained little recognition beyond their small boundary. ${ }^{61}$

have acquired a degree of recognition sufficient to be considered famous, particularly outside of the narrow market for commercial vacuums and floor cleaning."); Michael Caruso \& Co., Inc. v. Estefan Enterprises, Inc., 994 F. Supp. 1454, 1463 (S.D. Fla. 1998) ("Even if a mark is distinctive in its particular market, [this] does not render it inherently distinctive so as to engender immediate recognition in the general public of a particular product."), affd, 166 F.3d 353 (11th Cir. 1998).

One court did not find a plaintiffs mark famous though the mark has been in use and widely advertised for forty-six years in connection with eight grocery stores, while another court found a plaintiffs mark famous that had been in use for ninety years in connection with grocery store chains in the Northeast region. See Star Markets, 950 F. Supp. at 1034-36 (discussing the duration and extent of the plaintiffs use and advertising of its mark); Wawa, Inc. v. Haaf, 40 U.S.P.Q.2d (BNA) 1629, 1631 (E.D. Pa. 1996) ("Wawa is also a famous mark, having been used extensively in the convenience store business for almost 90 years."), affd, 116 F.3d 471 (3d Cir. 1997).

56 See Courtland L. Reichman, State and Federal Trademark Dilution, 17 FranCHISE L.J. 111,133 (1998) (discussing the "big fish in a small pond" theory).

57 See, e.g., Panavision Int'l, L.P. v. Toeppen, 141 F.3d 1316, 1327 (9th Cir. 1998) (maintaining that Toeppen's use of PANAVISION as a domain name is deceptive and would discourage potential Panavision customers); TeleTech Customer Care Management, Inc. v. Tele-Tech Co., Inc., 977 F. Supp. 1407, 1413 (C.D. Cal. 1997) (describing a number of factors indicating that the plaintiffs mark was probably famous for purposes of the Dilution Act); see also supra note 55 and accompanying text (discussing the applicable cases).

58 See infra note 57 and accompanying text (discussing applicable cases).

59 See supra notes 55-57 and accompanying text (discussing cases involving the use of domain names on the Internet where courts have applied the diminishment theory as an alternative to tarnishment and blurring, where consumers initially access the wrong website due to confusion over the correct domain name).

60 See Reichman, supra note 56, at 132 (illustrating the courts have been willing to stretch the fame requirement to accommodate Congressional intent).

61 See Nailtiques Cosmetic Corp. v. Salon Sciences Corp., 41 U.S.P.Q.2d (BNA) 1995, 1996-98 (S.D. Fla. 1997) (concluding a consideration of the factors enumerated in the Dilution Act weighed heavily in favor of finding the mark used by the plaintiff entitled to protection under the Act); Gazette Newspapers, Inc. v. New Paper, Inc., 934 F. Supp. 688, 690-91, 693 (D. Md. 1996) (finding the term "Gazette" to be "descriptive" and therefore entitled to protection under the Dilution Act). 


\section{B. No Guidance on How to Determine the Degree of Fame and Dilution}

The Dilution Act provides a list of eight non-exclusive factors for assessing distinctiveness and fame. ${ }^{62}$ However, those factors do not address how distinctive and famous the mark should be or what degree of fame, notoriety or recognition the mark should possess to qualify for protection under the Act. ${ }^{63}$ The Act neither defines nor identifies the quantitative measurements for determining fame. ${ }^{64}$ Moreover, while the Act requires a showing of actual dilution, it fails to provide any guidance on how to determine the degree of dilution once a mark is found to be famous. ${ }^{65}$ Most courts have interpreted the Act to include a 'likelihood of dilution' standard. ${ }^{66}$ However, in Ringling Bros. the Fourth Circuit rejected that standard and imposes a stringent actual dilution standard.67 The Dilution Act also fails to identify the quantitative measurements for determining whether a famous mark indeed has been diluted. ${ }^{68}$ As a re-

62 See supra note 23 and accompanying text (enumerating the applicable factors).

63 See Miles J. Alexander, Dilution and Famous MarkS FOR ADVANCEd TRAdEMARK PRACTITIONERS 3, 3 (nternational Trademarks Association ed., 1998) (course materials, on file with Albany Law Review) (discussing the limitations of the Dilution Act); see also Susan L. Serad, Comment, One Year After Dilution's Entry into Federal Trademark Law, 32 WAKE FOREST L. REV. 215, 234 (1997) (discussing the quandary for business owners trying to determine whether a mark is famous).

64 See Serad, supra note 63 , at 234 (noting "unless a mark is clearly famous, either party may be successful depending upon how a court chooses to interpret [the Dilution Act's] factors).

65 See Ringling Bros.-Barnum \& Bailey Combined Shows, Inc. v. Utah Div. of Travel Dev., 955 F. Supp. 605, 613, 616 (E.D. Va. 1997) (commenting "the Act does not specify how dilution occurs or how it may be detected or measured," and suggesting that "[b]ecause the effect of blurring may manifest itself directly in harm to the selling power of the famous mark, dilution by blurring may be shown by proof that the use of a junior mark has caused a lessening of demand for the product or services bearing the famous mark" as evidenced by a survey of consumers or circumstantially by the application of a multi-factor balancing test), aff'd, 170 F.3d 449 (4th Cir. 1999).

66 See, e.g., Mead Data Center, Inc. v. Toyota Motor Sales, U.S.A., Inc., 875 F.2d 1026, 1035 (2d Cir. 1989) (establishing a balancing test of several factors to be used when applying the likelihood of dilution standard); Elvis Presley Enter., Inc. v. Capece, 950 F. Supp. 783 797-98 (S.D. Tex. 1996) (" $[\mathrm{A}]$ finding of dilution in the present case depends on whether there is the likelihood of dilution."), rev'd, 141 F.3d 188 (5th Cir. 1998); Clinique Labs., Inc. v. Dep Corp., 945 F. Supp. 547, 562 (S.D.N.Y. 1996) (applying likelihood of dilution factors for finding dilution by blurring).

67 Ringling Bros., 170 F.3d at 458 (stating that "the federal Act ... provides remedy only for actual, consummated dilution"); see also Patrick M. Bible, Comment, Defining and Quantifying Dilution Under the Federal Trademark Dilution Act of 1995: Using Survey Evidence to Show Actual Dilution, 70 U. COLO. L. REv. 295, 307 (1999) (observing that the Dilution Act suggests that the plaintiff must show actual dilution).

68 See Alexander, supra note 63 (discussing the limitations of the Dilution Act). 
sult, no court in analyzing the Act has provided a minimum threshold for finding dilution either under the likelihood of dilution or actual dilution standard.69 In short, proving fame and dilution under the Act at present is a costly and uncertain expedition into the new Wild West for trademark owners attempting to get protection under the new law.

\section{The Wasteland of Case Law in the New Wild West}

With such limitations, it is not surprising to discover that there are only four cases where courts have addressed quantitative measurements of fame or dilution in analyzing whether dilution has been proven by the plaintiff. ${ }^{70}$ Most courts seem to shy away from this uncharted jurisprudence territory. ${ }^{71}$ Courts continue to apply the six pronged test formulated by Judge Sweet ten years ago in his concurring opinion in Mead Data Center Inc. v. Toyota Motor Sales $^{72}$ in order to determine whether the plaintiff has proved dilution through blurring. ${ }^{73}$

When analyzing dilution under the Mead Data test, courts evaluate:

69 See generally Bible, supra note 67 , at 310-13 (discussing the various standards courts have used in the likely and actual dilution contexts).

70 See Ringling Bros., 170 F.3d at 463 (affirming the plaintiffs consumer survey evidence did not support a finding of dilution); Hershey Foods Corp. v. Mars, Inc., 998 F. Supp. 500, 515, 518-19 (M.D. Pa. 1998) (considering plaintiffs survey evidence in addressing fame and dilution issues); Star Markets, Ltd. v. Texaco, Inc., 950 F. Supp. 1030, 1033 (D. Haw. 1996) (finding plaintiffs secondary meaning survey results to be relevant to the distinctiveness inquiry); Wawa, Inc. v. Haaf, 40 U.S.P.Q.2d (BNA) 1629, 1632 (E.D. Pa. 1996) (holding plaintiffs market survey supported a conclusion that defendant's mark was undermining the strength of the plaintiff s mark), aff'd, 116 F.3d 471 (3d Cir. 1997); see also infra notes 88-208 and accompanying text (providing more detailed analysis of the applicable cases).

71 Cf. Ringling Bros., 170 F.3d at 464 (positing the difficulty in proving actual dilution may have led some courts to adopt an interpretation of the act that does not require actual dilution).

72875 F.2d 1026 (2d Cir. 1989).

73 See, e.g., Nabisco, Inc. v. PF Brands, Inc., 50 F. Supp.2d 188, 202, 205.09 (S.D.N.Y. 1999) (utilizing each of the six prongs outlined in Mead Data), aff'd, No. 99-7149(L), 1999 WL 672575 (2d Cir. Aug. 31, 1999); Hershey Foods, 998 F. Supp. at 520-21 (using only five of the six Mead Data factors); Ringling Bros.-Barnum Bailey Combined Shows, Inc. v. Utah Div. of Travel Dev., 955 F. Supp. 605, 618.21 (E.D. Va. 1997) (applying only five of the Mead Data factors), aff'd, 170 F.3d 449 (4th Cir. 1999); Clinique Labs., Inc. v. Dep Corp., 945 F. Supp. 547, 562-63 (applying each of the six prongs of the Mead Data test); Wawa, 40 U.S.P.Q.2d (BNA) at 1632-33 (applying each of Mead Data's factors); Ringling Bros.-Barnum \& Bailey Combined Shows, Inc. v. B.E. Windows Corp., 937 F. Supp. 204, 211-14 (S.D.N.Y. 1996) (using all six factors). 
(1) the similarity of the plaintiff's mark and defendant's mark;

(2) the similarity of the products covered by the marks;

(3) the sophistication of consumers;

(4) whether defendant has adopted the mark with predatory intent;

(5) renown of the senior mark; and

(6) renown of the junior mark. ${ }^{74}$

However, the Mead Data test includes factors that are not required under the Dilution Act. 'Predatory intent' clearly is not a factor in a dilution analysis under the Lanham Act. ${ }^{75}$ Also, the 'similarity of the products' factor is improper in determining dilution by blurring because it focuses on likelihood of confusion and is contrary to the Congressional intent under the Dilution Act. ${ }^{76}$

Some courts have taken the easy way out by summarily finding (or not finding) fame without engaging in much analysis. ${ }^{77}$ Other courts erroneously apply the inherent distinctiveness or secondary meaning analysis under section 43(a) of the Lanham Act to the fame analysis under the Dilution Act. ${ }^{78}$ Some courts go so far as to conclude that a mark has been diluted without evaluating how the mark has been diluted and the degree of such dilution. ${ }^{79}$ As noted above, the Fourth Circuit has declared that the Dilution Act re-

\footnotetext{
74 Mead Data, 875 F.2d at 1035.

75 See Clinique Labs., 945 F. Supp. at 562 n.22 (stating "predatory intent is not a factor in a dilution analysis under [the Act]").

76 See Gregg Duffey, Trademark Dilution Under the Federal Trademark Dilution Act of 1995: You've Come a Long Way Baby-Too Far, Maybe?, 39 S. TEx. L. REV. 133, 164 (1997) (encouraging courts to adopt a modified Mead Data test to determine dilution by blurring).

77 See America OnLine, Inc. v. LCGM, Inc., 46 F. Supp.2d 444, 450 (E.D. Va. 1998) (requiring the plaintiffs mark to be distinctive in order for protection under the Dilution Act and finding the plaintiffs mark distinctive without analyzing many of the factors enumerated under the measure); Nabisco, Inc. v. PF Brands, Inc., No. 99-7149(L), 1999 WL 672575, at *4-5 (2d Cir. Aug. 31, 1999) (finding the plaintiffs mark was famous without engaging in the fame analysis while conducting a distinctiveness analysis to determine whether the plaintiff s mark was distinctive for the protection provided under the Act), affg, $50 \mathrm{~F}$. Supp.2d 188, 201 (S.D.N.Y. 1999).

78 See, e.g., Gazette Newspapers, Inc. v. New Paper, Inc., 934 F. Supp. 688, 696 (D. Md. 1996) (concluding under the Dilution Act the factors to be considered in determining whether a mark is famous are "in large part the same factors" as in the trademark infringement test).

79 See, e.g., Acxiom Corp. v. Axiom, Inc., 27 F. Supp. 2d 478, 506 (D. Del. 1998) (finding “it is not necessary to determine whether Axiom's actions infringing Acxiom's marks also violate [the Dilution Act]" because dilution law is "similar to trademark infringement laws ... in scope and provide[s] similar remedies").
} 
quires trademark owners to show actual economic harm incurred by the famous mark due to the diluter's use of the junior mark. ${ }^{80}$

Many courts treat a dilution claim as an add-on claim, devoting more attention to the traditional trademark infringement claim..$^{81}$ It is not surprising that analyses of dilution as an add-on claim are sparse, superficial or erroneous. ${ }^{82}$ Many courts even ignore dilution claims completely upon finding likelihood of confusion. ${ }^{83}$ As a result, dilution jurisprudence has not evolved at a pace trademark owners would have hoped and has not provided trademark owners with clear guidance in evaluating whether a dilution claim should be asserted and, consequently, has not deterred meritless trademark litigation. ${ }^{84}$

The following section will focus on four reported cases that quantitatively measure fame and/or dilution.

\section{Measuring AND PROVING FAME AND Dilution}

Since the enactment of the Dilution Act there are few cases addressing the measurement of fame and/or dilution or how to prove fame and dilution using quantitative evidence. ${ }^{85}$ Furthermore, there are only four reported cases where federal courts have paid attention to and discussed survey evidence in measuring fame and dilution. ${ }^{86}$ Among these cases, there is only one circuit court decision which has been recently decided that addresses proof of dilu-

80 See infra notes 166-207 and accompanying text (discussing Ringling Bros.-Barnum \& Bailey Combined Shows, Inc. v. Utah Div. of Travel Dev., 955 F. Supp. 605, 613, 616 (E.D. Va. 1997), aff'd, 170 F.3d 449 (4th Cir. 1999)).

81 See, e.g., Rock and Roll Hall of Fame and Museum, Inc. v. Gentile Prods., 134 F.3d 749, 753 (6th Cir. 1998) (vacating the trial court's injunction solely on the basis that the defendant likely did not infringe on the plaintiffs trademark, with no mention of the plaintiffs dilution claim); Cumberland Packing Corp. v. Monsanto Co., 32 F. Supp.2d 561, 581 (E.D.N.Y. 1999) (disposing of the plaintiffs dilution claim in one paragraph).

82 See, e.g., Sunbeam Products v. The West Bend Co., 123 F.3d 246, 259-60 (affirming the district court's decision granting an injunction in favor of the plaintiff on trademark infringement grounds only); Gazette Newspapers, 937 F. Supp. at 696 (applying an erroneous understanding of an infringement standard when analyzing fame under the Dilution Act).

83 See, e.g., Rock and Roll Hall of Fame, 134 F.3d at 753 (vacating the trial court's injunction with no mention of the plaintiffs dilution claim).

84 See Reichman, supra note 56, at 114 (noting the dilution doctrine has some fundamental inconsistencies, and that the Dilution Act has caused a "dramatic increase" in dilution claims).

85 See Bible, supra note 67, at 317 (noting "only a few federal courts have dealt with survey evidence in dilution cases").

86 See infra notes 88-208 and accompanying text (discussing the application of the Dilution Act in four cases). 
tion using quantitative evidence. ${ }^{87}$ No circuit court has opined on both proof of fame and dilution. This suggests that the Wild West of trademark dilution is yet to be explored and settled, so that its wasteland of case law will be replaced with a navigable land of case law for trademark owners.

This section will discuss the four cases in chronological order.

\section{A. Wawa, Inc. v. Haaf ${ }^{88}$}

In Wawa, Inc. v. Haaf, the plaintiff owned and operated 500 convenience stores in the Northeast area, including Pennsylvania. ${ }^{89}$ The plaintiff had used the WAWA mark in connection with its convenience stores for approximately ninety years. ${ }^{90}$ The plaintiff had also extensively advertised its WAWA mark to the public with an annual advertising budget of $\$ 6$ million. ${ }^{91}$ In 1995, the defendants opened a convenience store within ten miles of one of plaintiff's stores.92 Defendants used the HAHA mark for their convenience store and had spent less than $\$ 500$ in advertising their store. ${ }^{93}$ The plaintiff brought a dilution claim against defendants for the use of the HAHA mark in connection with the defendant's convenience store. ${ }^{94}$

The Federal District Court for the Eastern District of Pennsylvania granted plaintiffs a permanent injunction against defendants for use of the HAHA mark. ${ }^{95}$ The court held that such use diluted the plaintiff's WAWA mark for its convenience store chain. ${ }^{96}$

The court applied the Dilution Act and found the plaintiff's WAWA mark was famous because the plaintiff had used the mark for almost ninety years and had extensively advertised to the public. ${ }^{97}$ The court analyzed whether the defendant's use of the HAHA

87 See infra notes 166-208 and accompanying text (discussing Ringling Bros.-Barnum \& Bailey Combined Shows, Inc. v. Utah Div. of Travel Dev., 955 F. Supp. 605, 613, 616 (E.D. Va. 1997), affd, 170 F.3d 449 (4th Cir. 1999)).

8840 U.S.P.Q.2d (BNA) 1629 (E.D. Pa. 1996), affd, 116 F.3d 471 (3d Cir. 1997).

89 See id. at 1631.

90 See id.

91 See id.

92 See id.

93 See id.

94 See id. at 1630 .

95 See id. at 1633 .

96 See $i d$. (noting the "[p]laintiff... established that its mark [would] be diluted either through blurring or parody").

97 See id. at 1631. 
mark diluted the plaintiff's famous WAWA mark. ${ }^{98}$ In determining dilution, the court relied, in part, on the plaintiff's survey evidence which indicated that $29 \%$ of the respondents associated defendant's Haha market with plaintiff's Wawa convenience stores. ${ }^{99}$ The court found that the survey evidence supported its conclusion that defendant's HAHA mark was "undermining the strength of Wawa either through dilution or parody." 100

The Wawa court was the first court, in finding dilution under the Act, to rely on survey evidence. ${ }^{101}$ It did so without having the benefit of precedent on quantitative measurement to determine dilution. The court, unfortunately, failed to explain why $29 \%$ constituted a reliable percentage for finding dilution. Moreover, with respect to the fame issue, the court did not discuss the plaintiff's fame survey of its WAWA mark. Since the opinion was silent on this issue, trademark owners have been left to wonder why the court did not rely on this evidence when concluding that the WAWA mark was famous.

In contrast to the Wawa court, the federal District Court for Hawaii addressed survey evidence on the fame issue.102 That court, however, stopped its analysis upon finding that the plaintiff's mark was not famous. ${ }^{103}$ Accordingly, it was unnecessary to analyze dilution absent fame. ${ }^{104}$ The next section will focus on that decision.

B. Star Markets, Ltd. v. Texaco, Inc. ${ }^{105}$

In Star Markets, Ltd. v. Texaco, Inc., the court held that the plaintiff's STAR MARKET mark for grocery stores was not sufficiently famous to merit protection from dilution pursuant to the

98 See id. at 1631-33.

99 See id. at 1632 .

100 Id. The court also applied the test formulated in Mead Data Center, Inc. U. Toyota Motor Sales, Inc., 875 F.2d 1026 (2d Cir. 1989), to analyze whether dilution had been proved. The court found that a balance of the six factors favored the plaintiff. See Wawa, 40 U.S.P.Q.2d (BNA) at 1632.33 (applying all six factors of the Mead Data test).

101 See Eric A. Prager, The Federal Trademark Dilution Act of 1995: Substantial Likelihood of Confusion, 7 FORdhaM INTEll. Prop. Media \& ENT. L.J. 121, 133 (1996) (noting Wawa was the first applicable decision rendered after the enactment of the Dilution Act that relied, at least in part, on survey evidence).

102 See infra notes 105-36 and accompanying text (discussing Star Markets, Ltd. v. Texaco, Inc., 950 F. Supp. 1030 (D. Haw. 1996)).

103 See infra notes 105-06 and accompanying text (discussing factual conclusions).

104 See infra note 136 and accompanying text (analyzing the court's determinations).

105950 F. Supp. 1030 (D. Haw. 1996). 
Act. ${ }^{106}$ The plaintiff had used the STAR MARKET trademark in association with the operation of its supermarket business in Hawaii since 1946. ${ }^{107}$ The plaintiff had eight grocery stores in Oahu, Maui and Kauai. ${ }^{108}$ Defendant had operated gasoline stations throughout the United States, including the state of Hawaii. ${ }^{109}$ Defendant also offered convenience store services in connection with some of its Hawaiian gasoline stations. ${ }^{110}$ Defendant had used the mark STAR MART in connection with the operation of seventeen of its convenience stores/gasoline stations in Hawaii. ${ }^{111}$ The plaintiff brought a dilution claim against defendant Texaco for its use of the STAR MART trademark. ${ }^{112}$

The Star Market court applied all eight factors enumerated in the Dilution Act in analyzing whether the plaintiff's mark was famous. ${ }^{113}$ In tackling the degree of distinctiveness, plaintiff utilized a secondary meaning consumer survey which measured the association between the word STAR and plaintiff's grocery stores. ${ }^{114}$ More than $75 \%$ of the respondents made the association. ${ }^{115}$ Accordingly, the secondary meaning survey established that the plaintiff's mark had acquired distinctiveness. ${ }^{116}$ Acquired distinctiveness, the court noted, is merely a minimum threshold for establishing protectibility of a trademark that is not ordinarily entitled to protection under trademark law. ${ }^{117}$ Though the secondary meaning survey did not measure the strength of the plaintiff's mark, a high percentage of respondents made the association between the word STAR and plaintiff's grocery stores, suggesting that the "[p]laintiff's mark possess[ed] more than the bare minimum degree of distinctiveness, but less than a high level of distinctiveness." 118 The court concluded that the distinctiveness factor "slightly favor[ed] the plaintiff."119

\footnotetext{
106 See id. at 1036.

107 See id. at 1031.

108 See id.

109 See id.

110 See id.

111 See id.

112 See id.

113 See id. at 1033-36 (noting factors illustrated in 15 U.S.C. $\$ 1125$ (1994)).

114 See id. at 1033; see also supra note 23 and accompanying text (enumerating the Dilution Act's first factor: "the degree of inherent or acquired distinctiveness of the mark").

116 See Star Markets, 950 F. Supp. at 1033.

116 See id.

117 See id.

118 Id. at 1033-34.

119 Id. at 1034 .
} 
The plaintiff also conducted a recognition survey, also known as the fame survey, for the factors related to "[u]se and degree of recognition within the channels of trade." 120 The recognition survey, which, like the secondary meaning survey, was conducted only in Hawaii, revealed that over $96 \%$ of the respondents recognized plaintiffs STAR MARKETS mark when they were asked "the names of any grocery stores or supermarkets they could remember." ${ }^{21}$ Further, more respondents in Hawaii recognized plaintiff's mark than DUPONT, a mark recognized as nationally famous in the legislative history of the Dilution Act. ${ }^{122}$ Although the court ruled for the plaintiff on this factor, it noted that the recognition survey was conducted solely in Hawaii and thus the comparison between the plaintiff's mark and a nationally famous mark like DUPONT was not helpful. ${ }^{123}$

The duration and extent of the plaintiff's use and advertising was also found to favor the plaintiff since it had used the mark for fortysix years in connection with its grocery stores and had extensively advertised the mark during the same time period. ${ }^{124}$ However, the court ruled for the defendants on the remaining factors, all of which the court believed to be important in determining whether the mark was famous. ${ }^{125}$ The court found that with respect to the geographic trading area, the plaintiff had used its mark for grocery stores in only one state. ${ }^{126}$ The court found that "fame in only one state militates strongly against meriting protection from dilution under federal law."127 The court further noted that the use of a mark "must extend throughout a substantial portion of the U.S." 128 Likewise, the court found for the defendant on the use by third parties fac-

120 Id. at 1035; see also supra note 23 and accompanying text (noting the wording of the Dilution Act's fifth and sixth factors: "the channels of trade for the goods or services with which the mark is used; the degree of recognition of the mark in the trading areas and channels of trade used by the marks' owner and the person against whom the injunction is sought").

121 Star Markets, 950 F. Supp. at 1035.

122 See id. at 1034 (citing H.R. REP. No. 104-374, at 3 (1995), reprinted in 1995 U.S.C.C.A.N. 1029, 1030).

123 See Star Markets, 950 F. Supp. at 1035.

124 See id. at 1034; see also supra note 23 and accompanying text (enumerating the Dilution Act's third factor: "the duration and extent of advertising and publicity of the mark").

125 See Star Markets, 950 F. Supp. at 1034-36.

120 See id. at 1034; see also supra note 23 and accompanying text (enumerating the Dilution Act's fourth factor: "the geographical extent of the trading area in which the mark is used").

127 Star Markets, 950 F. Supp. at 1035.

128 Id. at 1034. 
tor. ${ }^{129}$ The court noted that numerous grocery, convenience and food-related stores use, at least in part, the name STAR or STAR MARKET and there is also a federal trademark registration of STAR MARKET'S for a grocery store chain owned by a third party. ${ }^{130}$ Moreover, the court noted that the plaintiff did not register its mark as considered by the Dilution Act. ${ }^{131}$ Accordingly, the court held that the "[p]laintiff's mark [was] not famous [in the context] of the Act." 132

Unlike the Wawa court that failed to address survey evidence on the fame issue, the Star Market court focused on survey evidence in its analysis of fame. The court's attention to survey evidence, however, was superficial. It relied on the plaintiff's survey evidence to make only one determination: the plaintiff's mark was distinctive, but not highly distinctive. ${ }^{133}$ The court failed to explain its reasons for accepting the survey evidence for distinctiveness in light of the fact that the court rejected the recognition survey for being conducted only in Hawaii. ${ }^{134}$ Moreover, the court did not suggest a cutoff percentage for a finding of distinctive versus highly distinctive.

While the court did not find the recognition survey helpful because it was conducted solely in Hawaii, it unexplainably credited the plaintiff for the degree of recognition within trade. ${ }^{135}$ A trademark owner, upon a review of this opinion, is then left to ponder whether a national recognition survey with a high percentage of respondents recognizing plaintiff's mark would assist the court's inquiry in assessing fame.

Since the court did not find plaintiff's mark to be famous, it did not analyze whether defendant Texaco's use of the mark STAR MARKET for convenience stores in connection with gasoline sta-

129 See id. at 1035-36; see also supra note 23 and accompanying text (enumerating the Dilution Act's seventh factor: "the nature and extent of use of the same or similar marks by third parties").

130 See Star Markets, 950 F. Supp. at 1035-36.

131 See id. at 1036; see also supra note 23 and accompanying text (enumerating the Dilution Act's eighth factor: "whether the mark was registered under the Act of March 3, 1881, or the Act of February 20, 1905, or on the principal register").

132 Star Markets, 950 F. Supp. at 1037.

133 See id. at 1033-34; see also supra notes 113-19 (discussing the court's analysis).

134 See Star Markets, 950 F. Supp. at 1035 ("Accepting Plaintiffs view of its fame relative to that of DuPont's within the state of Hawaii does not end the court's inquiry ... . [t]he examples in the legislative history of the Act [illustrate] nationally famous names.").

135 See id. at 1035; see also supra note 23 and accompanying text (enumerating the Dilution Act's fifth and sixth factors: "the channels of trade for the goods or services with which the mark is used; the degree of recognition of the mark in the trading areas and channels of trade used by the marks' owner and the person against whom the injunction is sought"). 
tions diluted the plaintiff's mark. ${ }^{136}$ This is unfortunate given the limited jurisprudence on the use of survey evidence in measuring and proving dilution. In the next two cases, however, the courts addressed survey evidence in relation to both fame and dilution issues.

\section{Hershey Foods Corp. v. Mars, Inc. ${ }^{137}$}

In Hershey Foods Corp. v. Mars, Inc., plaintiff Hershey claimed rights in a portion of its trade dress for its REESE'S peanut butter cups. ${ }^{138}$ The partial trade dress at issue consisted of "a unique shade of orange as the principal element in combination with and in juxtaposition to the colors yellow and brown, in an arrangement creating a distinctive overall appearance." 139 Defendant Mars, a manufacturer of candies, began to introduce peanut butter $M$ \& M'S candies in orange red packages. ${ }^{140}$ Hershey sued Mars for dilution of its partial trade dress. ${ }^{141}$ Hershey applied for a preliminary injunction enjoining the defendant from using its trade dress for peanut butter M \& M'S candy in violation of the Dilution Act. ${ }^{142}$ The court denied Hershey's motion for a preliminary injunction. ${ }^{143}$

To support its motion for a preliminary injunction under the Dilution Act, Hershey conducted a fame survey of consumers nationwide to determine the significance of the relationship between the products with respect to trade dress. ${ }^{144}$ The survey indicated that 94\% of respondents recognized a representation of the REESE'S trade dress as REESE'S. ${ }^{145}$ The representation retained the symmetrical pattern of the actual package wherein the word "REESE'S" was replaced by the logo "BRAND X" that was the same size and was styled and centered as it would be on the real package. ${ }^{146}$ The saw-toothed top of the peanut butter cup shape which appeared below the word "REESE'S" was modified to a rectangular shape. ${ }^{147}$

136 See Star Markets, 950 F. Supp. at 1037.

137998 F. Supp. 500 (M.D. Pa. 1998).

138 See id. at 502.

139 Id. at 514 (citations omitted).

140 See id. at 506.

141 See id. at 502.

142 See id.

143 See id. at 522.

144 See id. at 509.

145 See id. at 511.

146 See id. at 510.

147 See id. 
The court found that based on the survey the plaintiff's trade dress had acquired both distinctiveness and recognition by consumers. ${ }^{148}$ Ultimately, the court did not rely on the evidence contained in the survey when weighing the eight factors for finding fame as enumerated in the Dilution Act, stating that "[d]espite the evidence from the consumer survey, since plaintiff is not relying on its trade name, logo, and saw-toothed bar, the dress does not seem worthy of protection as famous." 149

Applying the enumerated fame factors of the Act, the court found in favor of the plaintiff on the first six factors: (A) the trade dress had acquired distinctiveness; (B) the trade dress, keylined yellow print on orange and brown packaging, had been in use for half a century in connection with peanut butter cups; (C) the plaintiff had spent more than $\$ 120$ million nationwide in advertising since 1990 alone; (D) the plaintiff's peanut butter cups appeared nationwide; (E) the channels of trade for the peanut butter cup candies with which the trade dress was used were widespread and extensive, and; (F) the trade dress was recognized by purchasers of both Hershey and Mars products. ${ }^{150}$

The court, however, found for defendant on the final two factors: (G) the nature and extent of use of similar marks by third parties and $(\mathrm{H})$ whether the trade dress had been federally registered. ${ }^{151}$ The court considered factors $\mathrm{G}$ and $\mathrm{H}$ the most important for purposes of determining whether a mark is famous. ${ }^{152}$ The other factors were not as important because most companies doing business nationwide are expected to satisfy them. ${ }^{153}$ The court found that there were a number of third-party marks in the food industry similar to the plaintiff's trade dress. ${ }^{154}$ Further, the court noted that the plaintiff had never federally registered its trade dress. ${ }^{155}$ The court concluded that the plaintiff's trade dress was not famous for the dilution claim. ${ }^{156}$

\footnotetext{
148 See id. at 515.

149 Id. at 515-17; see also supra note 23 and accompanying text (delineating eight nonexclusive factors enumerated in 15 U.S.C. $\$ 1125(c)(1)$ (1994) that a court may consider in determining whether a mark is distinctive and famous).

150 See Hershey Foods, 998 F. Supp. at 517.

151 See id.

152 See id. at 516-17.

153 See id.

154 See id.

155 See id.

156 See id. at 517-18.
} 
The court, however, did not stop its analysis there; it went on further to discuss dilution. For purposes of analyzing dilution, the court assumed that the plaintiff had established the fame of its trade dress. ${ }^{157}$ This analysis considered the dilution survey in which fifty-one percent of the respondents that were shown the $M$ \& M'S representation mistakenly identified it as a REESE'S product and approximately $49 \%$ of those respondents cited color as the reason for their misidentification. ${ }^{158}$ Recognizing that although "[t]here is no standard criteria for surveying for dilution," 159 the court nevertheless discounted the dilution survey because the plaintiff left out visual clues on the M \& M'S representation while allowing the REESE'S and other brands representation clues analogous to their real packages. ${ }^{160}$

The Hershey Foods court, in its finding of lack of fame, did not address the survey evidence for fame, completely ignoring the high percentage, $94 \%$, of recognition of the plaintiff's trade dress without explaining its reasons. Instead, the court seemed to focus its assessment of the fame issue on two factors: the number of thirdparty uses and federal registration of plaintiff's mark. ${ }^{161}$ Compared to the cases discussed above, the Hershey Foods court failed to respect the legislative intent behind the eight enumerated factors of the Dilution Act. ${ }^{162}$ The court, by according importance to only two enumerated factors, $(G)$ the number of third party uses, and $(H)$ federal registration of a mark, ignored the fact that building fame in a trademark is a long and costly process. ${ }^{163}$ To enjoy the fruits of that process, trademark owners need their long and extensively used trademarks recognized as famous and protected from dilution. ${ }^{164}$

157 See id. at 518.

158 See id.

159 Id.

160 See id. at 519. The Hershey Foods court also analyzed dilution using the Mead Data six-pronged test formulated by Judge Sweet. See id. However, the court found no dilution under that test. See id. at 519.21.

161 See id. at 517 (noting the issues of third-party users and federal registration were important factors for the court).

162 See supra notes 88-136 and accompanying text (discussing Wawa and Star Markets).

163 See supra note 23 and accompanying text (enumerating the Dilution Act's seventh and eighth factors: "the nature and extent of use of the same or similar marks by third parties" and "whether the mark was registered under the Act of March 3, 1881, or the Act of Febru. ary 20,1905 , or on the principal register").

164 See Prager, supra note 101, at 124 ("Dilution does not hurt consumers; it hurts trademarks and their owners. Trademark dilution law seeks to protect the trademark owner's rights in a mark itself."). 
The Hershey Foods court discredited the dilution survey evidence without providing guidance as to what would be acceptable dilution survey evidence. The court also did not provide guidance as to whether recognition survey evidence is helpful in assessing fame and whether there is a quantitative threshold that a mark must possess in order to enjoy fame status under the Dilution Act. Likewise, the court did not shed light on what should be the percentage cut-off establishing dilution. The Hershey Foods court, unfortunately, joined the above mentioned courts in creating a rough and uncertain landscape for trademark owners who want to believe that the Dilution Act has tamed the old Wild West. ${ }^{165}$

The next case demonstrates that the new Wild West is difficult to navigate. Further, it illustrates that trademark owners will soon discover that their search for stability and order in the dilution land is far from being reached.

D. Ringling Bros.-Barnum \& Bailey Combined Shows, Inc. v. Utah Division of Travel Development. ${ }^{166}$

In Ringling Bros.-Barnum \& Bailey Combined Shows, Inc. $v$. Utah Division of Travel Development, the plaintiff and its predecessors had used the mark THE GREATEST SHOW ON EARTH since 1872. ${ }^{167}$ Plaintiff's circus performed throughout the United States with an average of 1,000 shows per year for about 12 million people in 95 cities. ${ }^{168}$ On average, more than 70 million people each year were exposed to the THE GREATEST SHOW ON EARTH mark in connection with the Ringling Brothers Circus. ${ }^{169}$ Revenues derived from goods and services bearing the mark exceeded \$103 million for the most recent fiscal year. ${ }^{170}$ The plaintiff had extensively advertised its mark nationwide in "print advertising, radio, television, videos, outdoor billboards, direct-mail pieces, press announcements, posters, program books, souvenirs, and joint promotions with other companies." 171 Plaintiffs advertising expenditures for the fiscal

\footnotetext{
165 See supra notes 88-136 and accompanying text (discussing Wawa and Star Markets).

166955 F. Supp. 605 (E.D. Va. 1997), aff'd, 170 F.3d 449 (4th Cir. 1999).

167 See Ringling Bros.-Barnum \& Bailey Combined Shows, Inc. v. Utah Div. of Travel

Dev., 170 F.3d 449, 451 (4th Cir. 1999).

168 See id.

169 See id.

170 See id.

171 Id.
} 
year ending in January of 1997 were $\$ 19$ million. ${ }^{172}$ To protect its mark from unauthorized use, the plaintiff had expended a substantial effort to police the mark with an enforcement program. ${ }^{173}$ In 1961, the plaintiff obtained a federal registration for its mark promoting circus services. ${ }^{174}$

The defendant Utah Division of Travel Development, an agency of the State of Utah, began using the mark THE GREATEST SNOW ON EARTH in connection with Utah tourism services in 1962. ${ }^{175}$ The defendant had used its mark in advertisements every year, except in 1963, 1977 and 1989.176 The defendant's annual budget for advertising ranged from $\$ 300,000$ to $\$ 450,000.177$ Utah had also used the mark on its motor vehicle license plates. ${ }^{178}$ The defendant obtained a federal registration for its mark in 1997 despite plaintiff's opposition. ${ }^{179}$ The plaintiff then filed its dilution claim against defendant in the United States District Court for the Eastern District of Virginia. ${ }^{180}$ The plaintiff lost after a bench trial. ${ }^{181}$

On appeal, the Fourth Circuit affirmed the district court's judgment that the phrase THE GREATEST SNOW ON EARTH did not dilute plaintiff Ringling's mark THE GREATEST SHOW ON EARTH in violation of the Dilution Act. ${ }^{182}$ The Fourth Circuit held that the Dilution Act proscribes only actual consummated dilution and requires proof of harm to the famous mark's selling power, not to its distinctiveness. ${ }^{183}$ The court conceded that its interpretation confines claims under the Dilution Act to a narrower scope than dilution claims under state anti-dilution statutes. ${ }^{184}$

The Fourth Circuit did not address the fame issue because the plaintiff "put on essentially undisputed evidence demonstrating that its mark had achieved 'famous' status before Utah began use of

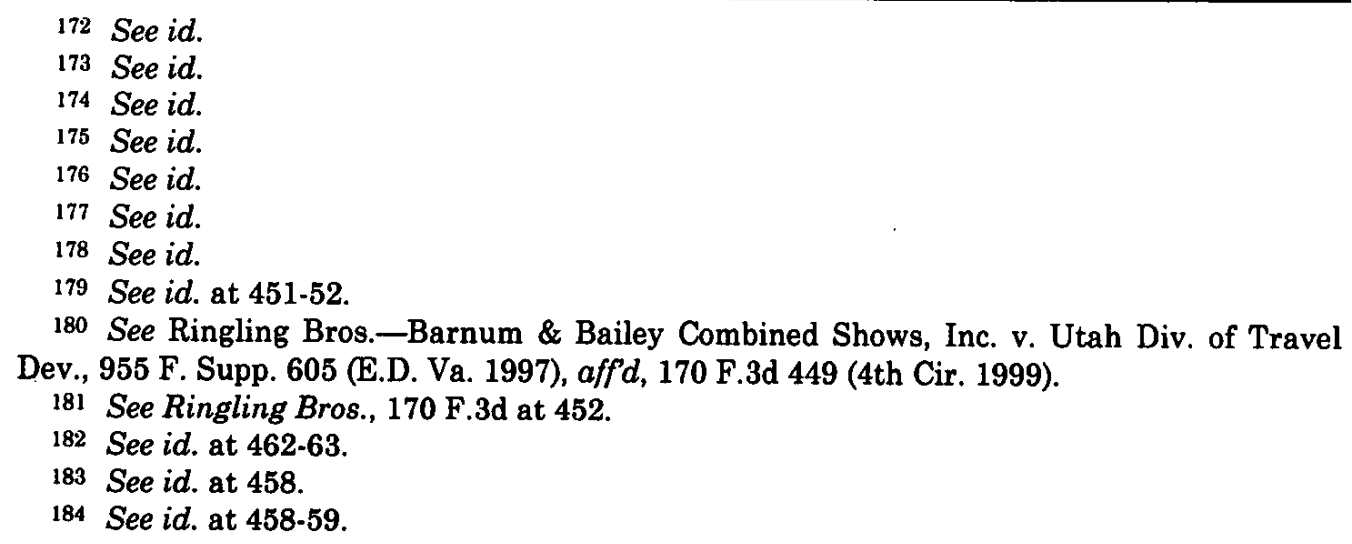


its mark." 185 Indeed, the district court, at trial, did not engage in an extensive analysis of the fame issue and summarily concluded that the plaintiff's mark was famous. 186 The survey evidence demonstrating that over $40 \%$ of respondents in the United States, both inside and outside of Utah, were able to complete the phrase THE GREATEST ON EARTH with the word SHOW and to associate that mark with the Ringling Brother's Circus, left the issue of fame undisputed. ${ }^{187}$

With respect to the dilution analysis, the Fourth Circuit affirmed the district court's assessment that the survey evidence failed to show that the "use of Utah's junior mark had caused any actual harm to Ringling's mark in the form of a lessening of that mark's former capacity to identify and distinguish Ringling's circus as its subject." 188 At trial the plaintiff offered a consumer survey as direct evidence of actual dilution. ${ }^{189}$ Specifically, the plaintiff contented that, within Utah, only $25 \%$ of respondents, compared to $41 \%$ nationwide, associated the incomplete statement THE GREATEST ON EARTH with Ringling alone, arguing that defendant's use of its mark has caused Utah residents to associate the uses of plaintiff's and defendant's marks. ${ }^{190}$ The district court rejected the plaintiff's argument. 191 The court interpreted the survey results to suggest the opposite since $46 \%$ of respondents in Utah, compared to 41\% elsewhere, associated THE GREATEST SHOW ON EARTH

185 Id. at $\mathbf{4 5 2}$.

186 See id.

187 See Ringling Bros.-Barnum \& Bailey Combined Shows, Inc. v. Utah Div. of Travel Dev., 955 F. Supp. 605, 612 (E.D. Va. 1997), aff'd, 170 F.3d 449 (4th Cir. 1999). The survey results in Utah were as follows:

(i) $25 \%$ of the respondents completed the statement THE GREATEST ON EARTH

with only the word SHOW and associated the completed statement with the Circus; (ii) $\mathbf{2 4 \%}$ completed [the] statement with only the word SNOW and associated the completed statement with [defendant]; and (iii) $21 \%$ of respondents completed [the] statement with SHOW and associated the result with the Circus and also completed this statement with SNOW and associated the completed statement with Utah. So in Utah, a total of $46 \%$ of respondents completed the statement THE GREATEST __ ON EARTH with the word SHOW and associated the completed statement with the Circus, and a total of $45 \%$ of respondents completed that statement with the word SNOW and associated the completed statement with Utah.

Id. Outside Utah, (i) $41 \%$ associated the statement with the Circus; (ii) $0 \%$ associated it with the defendant, and; (iii) fewer than $\mathbf{0 . 5 \%}$ associated it with the Circus and the defendant. See id. at 612-13.

188 Ringling Bros., 170 F.3d at 463.

189 See Ringling Bros., 955 F. Supp. at 616 (contending survey evidence demonstrated directly that the marks of both the plaintiff and defendant were associated within Utah).

190 See id.

191 See id. 
with Ringling. ${ }^{192}$ It reasoned that plaintiff's survey evidence disproved, not proved, dilution. ${ }^{193}$ The power of plaintiff's famous mark to identify and distinguish Ringling circus remained as strong within Utah as it did outside of Utah. ${ }^{194}$ Thus, there was no actual dilution of plaintiff's mark. ${ }^{195}$

In comparison to Star Market, where the court seemed to suggest that a recognition survey is useful for the fame analysis if it is conducted nationwide and yet failed to indicate what the acceptable quantitative measurement should be for a nationwide recognition survey, the district court seemed to be comfortable with the $40 \%$ consumer recognition of plaintiff's mark in a nationwide consumer survey. ${ }^{196}$ Accordingly, the fame of the plaintiff's mark was measured and it satisfied the first requirement under the Dilution Act. ${ }^{197}$

Both the Fourth Circuit and the District Court misapplied the dilution law. By requiring proof of actual economic harm to the famous mark's selling power, each court misinterpreted the survey evidence, concluding that no dilution was shown. ${ }^{198}$ This interpretation is at odds with the dilution through blurring concept, which does not require consumers in the defendant's market to be confused or mistaken in their associations of the famous mark and the junior mark. ${ }^{199}$ Dilution occurs when consumers see the junior mark and then recall the senior mark and the goods or services associated with the senior mark. ${ }^{200}$ However, the consumers intuitively know by the context of the junior mark's use that there is no connection between the owner of the junior mark and the owner of the senior mark. ${ }^{201}$

\footnotetext{
192 See id. at 617.

193 See id.

194 See id.

195 See id. at 618.

196 See id. at 613 ("The facts reflect ... that Ringling's mark ... is a famous mark.").

197 See id. (noting that the defendant did not dispute that Ringling Brothers had satisfied this element of a dilution claim).

198 See generally Ringling Bros.-Barnum \& Bailey Combined Shows, Inc. v. Utah Div. of Travel Dev., 170 F.3d 449, 463 (4th Cir. 1999) (finding the lack of evidence of harm "suffices to support the court's ultimate conclusion").

199 See Reichman, supra note 56, at 112-13 ("Although not confused, the senior trademark's ability to uniquely distinguish one source is weakened because the mark no longer calls to mind a single association, but rather several marks.").

200 See id. at 112 ("Trademark dilution occurs when the ability of a mark to clearly and unmistakably distinguish one source and the quality of that source has been weakened.").

201 See id. ("Trademark dilution does not require a likelihood of confusion or competition between the goods the marks identify."); see also MCCARTHY, supra note 7, § 24:13, at 24-111 to -112 (noting dilution "presupposes no mental confusion over affiliation or connection, but rather a state of mind that recognizes independent sources and affiliation").
} 
The dilution survey evidence in Ringling Bros. demonstrated that consumers had made a mental association between Ringling Brother's famous mark and Utah's mark. ${ }^{202}$ If the Fourth Circuit and the district court had each correctly interpreted the Act and applied the dilution through blurring doctrine, such proof of mental association would be sufficient to show dilution. The Ringling Bros. courts would have then joined the Wawa court, which found support for its conclusion of dilution in the $29 \%$ of respondents who incorrectly associated defendant's HAHA mark with plaintiff's WAWA mark. ${ }^{203}$

With its erroneous reading of the Dilution Act, the district court rejected the dilution survey evidence without an in-depth discussion, merely stating that THE GREATEST __ ON EARTH phrase used in the survey was not exactly the plaintiff's mark in use. ${ }^{204}$ The Fourth Circuit agreed with the district court's conclusion of no dilution by pointing out that the survey evidence was designed to show only an 'instinctive mental association' of the two marks," not actual harm to the capacity of the famous mark to distinguish its goods or services caused by the use of the defendant's mark. ${ }^{205}$ According to both the Fourth Circuit and the district court, the survey evidence disproved dilution because plaintiff's mark enjoyed a higher degree of recognition in Utah than elsewhere. ${ }^{206}$ The Fourth Circuit's approval of the district court's analysis of the consumer survey is the most haunting part of the New Wild West: demonstrating high recognition through a consumer survey may be viewed as evidence of lack of actual injury to the capacity of the mark to identify and distinguish its goods or services. ${ }^{207}$

202 See Ringling Bros., 955 F. Supp. at 612-13 (noting the survey results).

203 See supra notes 88-104 and accompanying text (discussing Wawa, Inc. v. Haaf, 40 U.S.P.Q.2d (BNA) 1629 (E.D. Pa. 1996), aff'd, 116 F.3d 471 (3d Cir. 1997)).

204 See Ringling Bros., 955 F. Supp. at 617-18 (noting "the survey provides no direct evidence that this famous mark is diluted").

205 See Ringling Bros.-Barnum \& Bailey Combined Shows, Inc. v. Utah Div. of Travel Dev., 170 F.3d 449, 462 (4th Cir. 1999) (citations omitted).

206 See id. at 463 ("[T] he [district] court pointed to survey results indicating that consumer familiarity with Ringling's mark was greater in Utah (46\%), where Utah's mark was wellknown, than in the rest of the country (41\%), where Utah's mark was virtually unknown.").

207 See Reichman, supra note 56, at 135 (noting the Ringling Bros. courts failed to recog. nize that dilution "does not require consumers in the defendant's market to be confused or mistaken in their associations. Dilution occurs if a consumer thinks of both marks at the same time and properly recognizes that the mark identifies two sources."). Based on its misreading of dilution law, the Ringling Bros. courts each misinterpreted the survey evidence on dilution. See id. ("The court's analysis in Ringling Bros. misses the point of dilution."). 


\section{E. The Wasteland of Four Cases and No Direction}

In summary, only four cases have addressed survey evidence, and at the present time there is no guideline for measuring fame and dilution with quantitative evidence. ${ }^{208}$ In these cases, survey evidence has neither been properly analyzed nor greatly valued by the courts. The enumerated factors for determining fame are weighed by the courts, however, with strong emphasis on two factors-the number of third party uses and whether the plaintiff's mark has been registered. By according importance only to those two factors, the courts ignore enormous efforts, time, money, and creativity devoted by trademark owners towards building the goodwill and reputation of their trademarks. There is a need for a new guideline for measuring fame and dilution that would provide trademark owners with concrete guidelines for determining whether a dilution claim should be asserted, thus conserving judicial resources for meaningful litigation.

\section{TOWARD A NEW APPROACH FOR MEASURING/PROVING FAME AND DILUTION}

Given the limitations of the Dilution Act and the ways in which the courts have interpreted the Act, trademark owners would benefit from an approach that provides uniformity and consistency in measuring and proving fame and dilution. New approaches for measuring and proving fame and dilution have been suggested. ${ }^{209}$ One commentator has proposed a modified Mead Data test. ${ }^{210}$ The original Mead Data test as formulated by Judge Sweet includes the following factors: "(1) similarity of the marks (2) similarity of the products covered by the marks (3) sophistication of consumers (4) predatory intent (5) renown of the senior mark [and] (6) renown of the junior mark." 211 The commentator has proposed that a modified Mead Data test be adopted, and that factor (2), similarity of prod-

208 See supra notes 88.207 and accompanying text (discussing the four cases considering survey evidence: Ringling Bros., 170 F.3d 449; Hershey Foods Corp. v. Mars, Inc., 998 F. Supp. 500 (M.D. Pa. 1998); Star Markets, Ltd. v. Texaco, Inc., 950 F. Supp. 1030 (D. Haw. 1996); Wawa, Inc. v. Haaf, 40 U.S.P.Q.2d (BNA) 1629 (E.D. Pa. 1996), affd, 116 F.3d 471 (3d Cir. 1997)).

209 See, e.g., MCCARTHY, supra note 7, at 24-164 (proposing a redesigned method); Duffey, supra note 76 , at 163 (outlining a revised approach).

210 See Duffey, supra note 76, at 163 (proposing to omit one of the existing six factors).

211 Mead Data Central, Inc. v. Toyota Motor Sales, U.S.A., Inc., 875 F.2d 1026, 1035 (2d Cir. 1989). 
ucts, be eliminated as an element for claims under the Dilution Act. ${ }^{212} \mathrm{He}$ posits that the factor is improper for determining dilution because it focuses on likelihood of confusion and is thus contrary to the Congressional intent. ${ }^{213}$ Dilution can be found regardless of similarity of the products. ${ }^{214}$

Professor J. Thomas McCarthy has taken the above proposition several steps further, concluding that several factors are neither relevant nor helpful to a dilution blurring claim under the Dilution Act. ${ }^{215}$ Specifically, Professor McCarthy reasons that factor (2) is irrelevant because dilution through blurring "posits that the products are neither competitive nor related in the sense of producing confusion as to affiliation or connection ... [and federal dilution law intends to cover] cases of widely differing goods."216

Professor McCarthy also suggests that factor (3) has little place in blurring analysis since "more sophisticated and knowledgeable consumers will not think there is any connection [between the trademarks], but will recognize there are two independent sources of goods or services operating under the same or a similar mark."217 He posits that factor (4), predatory intent, is not relevant because "blurring ... occurs in customers' minds regardless of the junior user's intent." 218 Further, Professor McCarthy maintains that factor (6), renown of the junior mark, is unnecessary because blurring can occur regardless of the strength of the junior mark. ${ }^{219}$

While professor McCarthy is correct in his view that factors (2), (3), (4), and (6) are of little relevance to a dilution through blurring claim, he fails to recognize that factors (1) and (5) also have no place in a dilution analysis under the Dilution Act.

212 See Duffey, supra note 76, at 162.63 (reasoning the fact that dilution can occur absent a similarity in products, coupled with Congressional intent, demands that the similarity of products factor be omitted).

213 See id. (noting the "similarity of products' factor is especially not proper for determining blurring under the [Dilution Act]") (citations omitted); see also Steven E. Shapiro, Use of 'Mead Data' Test Dilutes the Dilution Act, NAT'L L.J., May 12, 1997, at C2 (noting the express language of the Dilution Act does not require the plaintiff to prove a likelihood of confusion).

214 See Duffey, supra note 76, at 162-63 (stating "lack of similarity of the goods ... should not defeat a dilution claim").

215 See MCCARTHY, supra note $7, \S 24: 94.1$, at 24-164 (stating "these factors are the offspring of classical likelihood of confusion analysis").

216 Id.

217 Id.

218 Id.

219 See id. $\S 24: 69$, at 24-165 (reasoning that blurring is unlikely only when the junior user's mark is so strong that when it is "seen in its marketplace context [it] triggers no recollection or thought of the senior users mark"). 
Under the Act, to be entitled to protection, a mark must be famous. ${ }^{220}$ Accordingly, it is unnecessary to analyze the renown of the senior mark because trademark owners must establish the fame requirement in order to demonstrate that the Act applies.

Likewise, factor (1), similarity of marks, is not helpful in cases where dilution results from a mark which is not that similar to the famous mark-comparing the HAHA mark to that of WAWA is an excellent example.221 Factor (1) also contradicts the Dilution Act because the Act does not require a diluting mark to be similar to the famous mark. This reflects the intention of the drafters of the Dilution Act-the measure covers all forms of dilution, such as blurring, tarnishment and diminishment. ${ }^{222}$ Under dilution through tarnishment, the diluting marks are often not comparable to the famous mark-take for example: ADULTSRUS.COM as opposed to TOYS R US. 223

Thus, a new approach need not consider any of the Mead Data factors. ${ }^{224}$ However, under the new approach, a plaintiff must address both fame and dilution in proving a claim under the Dilution Act. Some courts and commentators have chosen to ignore or pay very little attention to the fact that a claim under the Act requires proof of both fame and dilution. ${ }^{225}$ This omission can lead to an incomplete or perhaps erroneous analysis. For example, the Fourth Circuit in Ringling Bros. accepted the proposition that the plain-

220 See 15 U.S.C. $\$ 1125$ (c)(1) (1994) (providing "famous mark shall be entitled" to the protection of the Act).

${ }^{221}$ See supra notes 95-96 and accompanying text (noting in Wawa, Inc. v. Haaf, 40 U.S.P.Q.2d (BNA) 1629 (E.D. Pa. 1996), affd, 116 F.3d 471 (3d Cir. 1997), the court concluded that the defendant's HAHA mark was undermining the plaintiffs WAWA mark).

${ }_{222}$ See H.R. REP. NO. 104-374, at 2 (1995) ("The purpose of [the bill] is to protect famous trademarks from subsequent uses that blur the distinctiveness of the mark or tarnish or disparage it.").

223 See Toys "R" Us, Inc. v. Akkaoui, 40 U.S.P.Q.2d (BNA) 1836, 1838 (N.D. Cal. 1996) (concluding there was a strong likelihood that plaintiff would prevail on a claim that its TOYS "R" US family of marks were being diluted by defendant's use of ADULTS R US).

224 In Nabisco, the Second Circuit declined to adopt the Mead Data factors as a fixed test for dilution under the act. See Nabisco, Inc. v. PF Brands, Inc., No. 99-7149(L), 1999 WL 672575, at *17-18 (2d Cir. Aug. 31, 1999) (illustrating the reasoning behind the court's determination), aff'g, 50 F. Supp.2d 188, 201 (S.D.N.Y. 1999). The court reasoned that the test failed to include "pertinent" factors such as "actual confusion and likelihood of confusion, shared consumers and geographic isolation, the adjectival quality of the junior use, and the interrelated factors of duration of the junior use, harm to the junior user, and delay by the senior in bringing the action". Id.

225 See, e.g., Ringling Bros.-Barnum \& Bailey Combined Shows, Inc. v. Utah Div. of Travel Dev., 170 F.3d 449, 452 (4th Cir. 1999) (providing minimal discussion on fame); Bible, supra at note 67, at 295-340 (providing an excellent analysis on proof of dilution and yet failing to discuss proof of fame as a necessary component for a claim under the Dilution Act). 
tiff's mark was famous with only minimal discussion of fame. 226 Nevertheless, the Fourth Circuit held that the defendant's mark did not dilute the plaintiff's famous mark because, based on the survey evidence, the plaintiff's mark was still highly recognized by the customers within an applicable geographic region. ${ }^{227}$

As to the issue of fame, the new approach should accord all of the Dilution Act's enumerated factors the same level of importance. The enumerated factors include an analysis of: (A) the degree of the mark's distinctiveness; (B) the duration and extent of use of the mark; (C) the duration and extent of the mark's advertising and publicity; (D) the geographical extent of the area in which the mark is used; (E) the channels of trade for the things with which the mark is associated; $(F)$ the degree of recognition that the mark has in the trading areas and channels of trade; $(G)$ the third party use of the same or similar marks, and; $(\mathrm{H})$ whether the mark is federally registered. ${ }^{228}$

Under the new approach, a separate analysis of distinctiveness, independent from the fame analysis, should not be conducted. A separate analysis would place undue importance on distinctiveness, create redundancy, and ignore the mandates of the Dilution Act. Distinctiveness is merely one of eight factors to consider in determining "famous and distinctive." 229 This assessment is something the Second Circuit failed to recognize in its recent decision in $\mathrm{Na}$ bisco, Inc. v. PF Brands, Inc. ${ }^{230}$ In Nabisco, the Second Circuit neglected to engage in a comprehensive fame analysis, summarily accepting that the plaintiff's trademark was famous when used in association with its product. ${ }^{231}$ Instead, the court conducted a distinctiveness analysis, concluding that anti-dilution protection was granted "only to holders of distinctive marks." 232 By engaging in an analysis on distinctiveness and ignoring a complete fame analysis, the Second Circuit compromised the plain language of the Dilution

226 See Ringling Bros., 170 F.3d at 452 (noting only that the plaintiff had put on essentially undisputed evidence at trial that its mark was famous).

227 See id. at 463 (affirming that the junior mark was causing no actual harm to the senior mark).

228 See 15 U.S.C. $§ 1125$ (c)(1) (1994) (setting forth a non-exclusive list of factors to be considered in determining whether a mark is distinctive and famous).

229 See supra note 23 and accompanying text (discussing the eight factors enumerated in 15 U.S.C. § $1125(c)(1)(1994))$.

230 No. 99-7149(L), 1999 WL 672575 (2d Cir. Aug. 31, 1999), affg, 50 F. Supp.2d 188, 201

(S.D.N.Y. 1999).

231 See Nabisco, 1999 WL 672575, at *4-5 (illustrating the reasoning of the court).

232 Id. at ${ }^{*} 5$. 
Act. The Act states that protection is extended only to "the owner of a famous mark," not the owner of a famous and distinctive mark. ${ }^{233}$ A truly famous mark, worthy of anti-dilution protection, is presumed distinctive. ${ }^{234}$ The Act requires that the defendant's use "begin[] after the [plaintiff's] mark has become famous." 235 Again, the Act does not require the mark to be distinctive and famous. ${ }^{236}$ Rather, it includes distinctiveness as one of the eight factors to be considered by courts in determining whether a mark is worthy of anti-dilution protection. 237 It would be redundant to engage in two separate analyses, one for fame and the other for distinctiveness in order to determine whether a mark is entitled to the anti-dilution protection. ${ }^{238}$ Moreover, mandating a separate analysis for distinctiveness accords that factor more weight than any of the other the seven factors. Those factors are crucial to the understanding how a mark becomes famous and, consequently, entitled to antidilution protection.

The courts should not accord some factors more importance than others. ${ }^{239}$ To do so would cause the same mistake made by the $\mathrm{Her}$ shey Foods court which gave paramount importance to third party use of similar marks and whether the mark was registered. ${ }^{240}$ Such emphasis on two factors ignores the plain fact that trademark owners who successfully satisfy the other six factors have spent much time, resources and creativity building the fame of their marks over a long period of time in a large trading region and should be entitled to protection under dilution law. Such emphasis appears to grant diluters a complete defense-if a mark is not federally registered, it is free to grab. This contradicts the fundamental under-

23315 U.S.C. $\$ 1125(c)(2)(1994)$.

234 See, e.g., Star Markets, Ltd. v. Texaco, Inc., 950 F. Supp. 1030, 1032 (D. Haw. 1996) (noting the Act protects "truly famous marks, which are presumed distinctive, but not distinctive marks if they are not also sufficiently famous"); MCCARTHY, supra note 7, § 24.91, at 24-148 (reasoning that having a separate requirement for distinctiveness would be redundant).

23515 U.S.C. $\$ 1125$ (c)(1) (1994).

236 See supra note 23 and accompanying text (discussing the eight factors enumerated in 15 U.S.C. $\$ 1125(c)(1)(1994))$.

237 See supra note 23 and accompanying text (discussing applicable factors).

238 See MCCARTHY, supra note 7, § 24.91, at 24-148 (contending the Act does not include an independent requirement of distinctiveness).

239 See, e.g., Navistar Int'l Transp. Corp. v. Freightliner Corp., 49 U.S.P.Q.2d (BNA) 1116, 1119 (N.D. Ill. 1998) ("The dilution statute provides eight factors for determining whether a mark is famous, and although the statute does not say courts must consider all eight, neither does it say that any one of the factors is dispositive.").

240 See Hershey Foods Corp. v. Mars, Inc., 998 F. Supp. 500, 517 (M.D. Pa. 1998) (referring to these elements as "important factors"). 
standing of trademark jurisprudence, which reasons that rights in trademarks are established through use, not registration. ${ }^{241}$ Moreover, the Dilution Act clearly does not instruct the courts to focus more on some factors or less on others. ${ }^{242}$ The Act merely suggests that courts consider the eight non-exclusive factors in determining distinctiveness and fame. ${ }^{243}$

In addition, the new approach should have a strong emphasis on quantitative evidence and provide a clear percentage cut-off for recognition or fame. ${ }^{244}$ With such a bright line test, a trademark owner will have to think twice in determining whether to bring an action if survey evidence on the fame issue is weak and employs flawed methodology. Acceptable survey evidence should follow a sound methodology and should be conducted either in a large geographical region in the United States or nationwide. If a mark, in a nationwide survey, is known to more than $40 \%$ of the defendant's potential customers, the mark is sufficiently famous for purposes of the Dilution Act. ${ }^{245}$

With respect to the dilution issue, the new approach should not mirror the model of dilution through blurring erected by the Fourth Circuit in Ringling Bros. ${ }^{246}$ The Fourth Circuit erroneously interpreted the Dilution Act as requiring proof of dilution to be shown by actual economic harm to the famous mark's selling power caused

241 See, e.g., Hunting Hall of Fame Found. v. Safari Club Int'l, 6 U.S.P.Q.2d (BNA) 1765, 1771 (D. Ariz. 1987) (stating the law requires a "presently existing trade or business" for acquisition of trademark rights and that "[a] party need not obtain a registration to obtain $a$ protected right in a trademark").

242 See 15 U.S.C. $\$ 1125$ (c)(1) (1994) (failing to state that one factor should be given more consideration than another).

243 See id. (" $[\mathrm{A}]$ court may consider factors such as, but not limited to [the enumerated factors].").

244 Cf. Bible, supra note 67, at 195-340 (noting survey evidence should be used in measuring dilution, yet not discussing how fame should be measured).

245 See Ringling Brothers-Barnum \& Bailey Combined Shows, Inc. v. Utah Div. of Travel Dev., 955 F. Supp. 605, 613 n.4 (E.D. Va. 1996) ("Over $40 \%$ of respondents in the United States, both inside and outside of Utah, were able (i) to complete the incomplete phrase THE GREATEST ON EARTH with the word SHOW to form Ringling's mark, THE GREATEST SHOW ON EARTH, and (ii) to associate that mark with the Circus."), affd, 170 F.3d 449 (4th Cir. 1999). But see MCCARTHY, supra note 7, § 24:92, at 24-156 ("[A] mark should not be categorized as 'famous' unless it is known to more than 50 percent of the defendant's potential customers."). This author believes that $\mathbf{5 0} \%$ nationwide recognition is too high of a benchmark for trademark owners to meet.

246 See supra notes 188-207 and accompanying text (describing the court's reasoning which indicated that a plaintiff should be required to endure actual economic harm). 
through use of the junior mark. ${ }^{247}$ The court failed to recognize that dilution of a mark does not occur overnight. Dilution is a slow process whereby a multitude of small users can erode a famous mark's ability to uniquely signify a source. ${ }^{248}$

The Fourth Circuit insisted that the Dilution Act requires actual proof of economic harm, in part, because it provided that where willful conduct was shown, both compensatory and restitutionary relief may be awarded. ${ }^{249}$ This is nothing less than intellectual dishonesty. The Dilution Act encompasses the likelihood of dilution as well as actual dilution because it does not require proof of an actual lessening of the market power of the famous mark. ${ }^{250}$ It only requires proof of a "lessening of the capacity of a famous mark to identify and distinguish goods or services." ${ }^{251}$ The Fourth Circuit also conveniently forgot that compensatory or restitutionary relief, in trademark cases under the Lanham Act, is rarely granted by courts. ${ }^{252}$ Because actual economic injury to a mark is extremely difficult to demonstrate, injunctive relief is most often the remedy sought by trademark owners. ${ }^{253}$ While courts do grant monetary damages in cases where the defendant's conduct is willful, even then a defendant's willful conduct does not mean that actual economic harm to the famous mark has occurred or can even be measured. ${ }^{254}$

The Fourth Circuit offered three general means of demonstrating actual economic harm to a famous mark's selling power due to the

247 See Ringling Brothers-Barnum \& Bailey Combined Shows, Inc. v. Utah Div. of Travel Dev., 170 F.3d 449, 461 (4th Cir. 1999) (noting the court's acknowledgement that its holding would restrict the scope of the Dilution Act).

248 See MCCARTHY, supra note 7, § 24:94, at 24-160 to -61 (equating dilution to "being stung by a hundred bees").

${ }^{249}$ See Ringling Bros., 170 F.3d at 461 (noting economic harm must necessarily be consummated for such relief to be awarded).

250 See MCCARTHY, supra note $7, \S 24: 94$, at 24-160 to -61 (maintaining proof of actual loss is not necessary as long as there is proof of loss of the mark's capacity to be strong); see also Nabisco, Inc. v. PF Brands, Inc., No. 99-7149(L), 1999 WL 672575, at *18 (2d Cir. Aug. 31, 1999) (illustrating the court's disagreement with the Fourth Circuit's interpretation in Ringling Bros., $170 \mathrm{F.3d} 449$, and requiring only proof of likelihood of dilution), affg, $50 \mathrm{~F}$. Supp.2d 188, 201 (S.D.N.Y. 1999).

25115 U.S.C. $\$ 1127$ (1994).

252 See MCCARTHY, supra note 7 , $\$ 30: 58$, at $30-97$ (noting the "obvious ambivalence" of the judiciary toward monetary awards).

${ }_{253}$ See id. (noting plaintiffs attorneys often advise clients that an injunction should be considered a victory in trademark infringement actions).

254 See, e.g., Big O Tire Dealers v. Goodyear Tire \& Rubber Co., 561 F.2d 1365, 1373-76 (10th Cir. 1997) (finding malice on the defendant's part and awarding compensatory and punitive damages). 
use of a junior mark. ${ }^{255}$ First, proof of actual loss of revenues, as the court acknowledged, is available "most rarely."256 Second, relevant indirect evidence includes "contextual factors such as the extent of the junior mark's exposure, the similarity of the marks, [and] the firmness of the senior mark's hold."257 This author believes that such evidence is irrelevant, redundant, contrary to the language of the Act and Congressional intent and simply not helpful. The extent of the junior mark's exposure is only relevant in cases where the junior mark triggers "no recollection or thought of the [famous] mark at all" because dilution through blurring occurs regardless of whether the junior mark has an independent image and reputation. ${ }^{258}$ The similarity of the marks is not helpful because dilution occurs in cases where the junior mark is not that similar to the famous mark. ${ }^{259}$ The plain language of the Dilution Act does not even require that the junior mark be similar to the famous mark. Such a requirement will provide no protection to famous marks in cases brought under tarnishment or new diminishment theories. ${ }^{260}$ Accordingly, it runs contrary to a Congressional intent of a federal remedy that is broader than existing state antidilution statutes. The firmness of the senior mark's hold is a redundancy of the fame analysis - the Dilution Act only protects marks that are famous. ${ }^{261}$ Dilution analysis is unnecessary if the fame analysis reveals that the mark is not famous within the meaning of the Dilution Act. ${ }^{262}$

The Fourth Circuit's last suggested means of measuring economic harm, "is the skillfully constructed consumer survey designed not just to demonstrate 'mental association' of the marks in isolation, but further consumer impressions from which actual harm and cause might rationally be inferred." 263 Assuming that the actual

255 See Ringling Brothers-Barnum \& Bailey Combined Shows, Inc. v. Utah Div. of Travel Dev., 170 F.3d 449, 465 (4th Cir. 1999) (setting forth factors "without attempting to chart the exact shape and course of advocacy that might prove" a loss of selling power).

256 Id.

257 Id.

258 MCCARTHY, supra note 7, § 24:95, at 24-165.

250 See supra note 223 and accompanying text (discussing Toys "R" Us, Inc. v. Akkaoui, 40 U.S.P.Q.2d (BNA) 1836, 1838 (N.D. Cal. 1996)).

260 See supra notes 32-51 and accompanying text (discussing applicable theories).

261 See 15 U.S.C. $§ 1125$ (c) (1994) (providing "[r]emedies [solely] for dilution of famous marks").

262 See id. (listing factors that a court may consider when determining whether a mark is distinctive and famous for purposes of the Act).

263 Ringling Brothers-Barnum \& Bailey Combined Shows, Inc. v. Utah Div. of Travel Dev., 170 F.3d 449, 465 (4th Cir. 1999). 
harm requirement was the correct interpretation of the Dilution Act, the Fourth Circuit failed to address the degree of actual harm that would constitute dilution. While this author disagrees with this interpretation, she does agree with the court that survey evidence is most relevant in proving dilution.

To establish proof of dilution, survey evidence must meet a minimum threshold of at least $20 \%$ of respondents making a mental association between the famous mark and junior mark. ${ }^{264}$ The higher the percentage beyond the threshold, the greater the dilution. With such quantitative evidence, the parties may attempt to settle their case sooner. One commentator suggests that a dilution survey should also compare the percentage of respondents who are exposed to the junior mark to the percentage of respondents who are not exposed to the junior mark. ${ }^{265}$ The difference between the two numbers will indicate dilution. ${ }^{266}$ The commentator, however, failed to suggest a minimum threshold of difference between the two groups that would conclusively suggest dilution. ${ }^{267}$

Overall, the new approach will have a strong emphasis on survey evidence. Such emphasis is not novel in trademark law. Indeed, the new approach will find precedent in the developed body of law on traditional trademark infringement. ${ }^{268}$ Courts in trademark infringement cases have consistently relied on survey evidence in their findings of likelihood of confusion in violation of the Lanham Act. ${ }^{269}$ Survey evidence with a range of $25 \%$ to $50 \%$ is well accepted as solid support for a finding of a likelihood of confusion. ${ }^{270}$

264 See Bible, supra note 67 , at 335 (indicating a $15 \%$ to $20 \%$ percent requirement would be a typical survey minimum necessary for the court to find "infringement based on likelihood of confusion"). But see MCCARTHY, supra note 7, $\$ 24: 92$, at 24-156 (positing to be considered famous, a mark must be known to more than $50 \%$ of the defendant's potential customers).

265 See Bible, supra note 67, at 331-32 (noting such comparisons provide "the most authoritative evidence" of dilution).

266 See id. (suggesting the difference can demonstrate "that a mark has been diluted from some benchmark figure").

267 See id. (indicating a comparison may not be appropriate where the junior user's mark is new to the market).

268 See infra note 270 and accompanying text (identifying trademark infringement cases where courts have credited survey evidence).

269 See infra note 270 and accompanying text (discussing applicable cases).

270 See Piper Aircraft Corp. v. Wag-Aero, Inc., 741 F.2d 925, 935 (7th Cir. 1984) (finding $\mathbf{4 5 \%}$ percent confusion rate "high" and a factor "weighing strongly" in support of a likelihood of confusion); RJR Foods, Inc. v. White Rock Corp., 603 F.2d 1058, 1061 (2d Cir. 1979) (considering a $15 \%$ to $20 \%$ confusion rate to be evidence of confusion); James Burrough Ltd. v. Sign of the Beefeater, Inc., 540 F.2d 266, 279 (7th Cir. 1976) (noting a 15\% confusion rate cannot be considered de minimus); Blockbuster Entertainment Group v. Laylco, Inc., 869 F. 
Likewise, issues arising with survey evidence, such as bias, misleading questions and unreliable results, may be avoided by applying appropriate survey techniques. ${ }^{271}$ Accordingly, courts analyzing dilution measurements should look to the well developed body of law on survey evidence in trademark infringement cases for assistance in addressing those issues relating to survey evidence of dilution. 272

The new approach should also rely on anecdotal evidence of dilution. Anecdotal evidence of dilution, as in other areas of trademark law such as likelihood of confusion and trademark infringement, has been held as highly persuasive evidence. ${ }^{273}$ In the case of dilution through blurring, anecdotal evidence may consist of testimony from plaintiff's customers who declare that they have incorrectly associated plaintiff's famous mark with the junior mark when they came in contact with defendant's products or services. ${ }^{274}$ Where

Supp. 505, 514 (E.D. Mich. 1994) (concluding a survey showing a confusion rate of nearly $14 \%$ "[o]n balance . . . must be given some weight," and granting the plaintiffs request for a preliminary injunction); A.T. Cross Co. v. TPM Distrib., Inc., 226 U.S.P.Q. (BNA) 521, 523-24 (C.D. Minn. 1985) (finding survey results showing $43 \%$ and $34 \%$ confusion rates were entitled to "great weight" and demonstrated "actual confusion" and "by implication, that there was a strong likelihood of confusion"); Wendy's Int'l, Inc. v. Big Bite, Inc., 576 F. Supp. 816, 823-24 (S.D. Ohio 1983) (finding a $7 \%$ level of confusion among all age groups and a $21 \%$ level of confusion among consumers between eighteen and twenty-four years of age were not insignificant levels of confusion as a matter of law).

271 See Shashank Upadhye, Trademark Surveys: Identifying the Relevant Universe of Confused Consumers, 8 FORDHAM INTELL. PROP. MEDIA \& ENT. L. J. 549, 559 (1997) (detailing the criteria necessary for a trustworthy survey). In Nabisco, the Second Circuit showed apprehension over the relevance that should be attributed to survey evidence in dilution cases, indicating that such evidence was subject to manipulation and unreliable. See $\mathrm{Na}$ bisco, Inc. v. PF Brands, Inc., No. 99-7149(L), 1999 WL 672575, at *18 (2d Cir. Aug. 31, 1999), aff'g, 50 F. Supp.2d 188, 201 (S.D.N.Y. 1999).

272 One court has formulated seven standards that surveys should meet to be trustworthy: (1) the 'universe' was properly defined, (2) a representative sample of that universe was selected, (3) the questions to be asked of interviewees were framed in a clear, precise and non-leading manner, (4) sound interview procedures were followed by competent in. terviewers who had no knowledge of the litigation or the purpose for which the survey was conducted, (5) the data gathered was accurately reported, (6) the data was analyzed in accordance with accepted statistical principles, and (7) objectivity of the entire process was assured.

Toys "R" Us, Inc. v. Canarsie Kiddie Shop, Inc., 559 F. Supp. 1189, 1205 (E.D.N.Y. 1983); see also Bible, supra note 67, at 315 ("[I]t is important to design and conduct surveys using scientifically accepted methods so as to assure their admissibility and lend as much weight as possible to the findings.").

273 See Prager, supra note 101, at 131-32 (noting. "anecdotal evidence of actual confusion is highly persuasive in trademark infringement cases").

274 Cf. RJR Foods, Inc., 603 F.2d at 1061 (crediting anecdotal evidence of actual confusion in the likelihood of confusion context). But see Prager, supra note 101, at 131 ("It is difficult to conceive of anecdotal evidence of dilution by blurring."). 
there is dilution through tarnishment, anecdotal evidence may consist of testimony from plaintiff's customers who declare that they have stopped purchasing plaintiff's products because they think the quality of the products have declined when, in fact, the quality remains the same. ${ }^{275}$

\section{CONCLUSION}

The Dilution Act was a significant development in trademark law, intended to protect a trademark owner's property-famous marks-and provide a federal remedy to the owner. ${ }^{276}$ The Act, however, has many limitations with respect to quantifying fame and dilution. These limitations can be overcome with a new approach that emphasizes both qualitative and quantitative evidence. The quantitative evidence on fame and dilution is useful to trademark owners in assessing the strength of their case prior to initiating litigation.

The new approach will further encourage more consistent analysis and provide trademark owners with clear guidance as to measuring and proving fame and dilution prior to initiating litigation based on dilution grounds.

275 See Prager, supra note 101, at 131-32 (imagining anecdotal evidence of dilution by tarnishment).

276 See supra notes 3-6 and accompanying text (discussing the impact of the Dilution Act on trademark owners). 